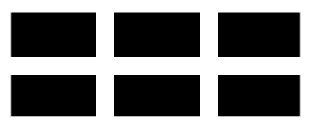

THE WILLIAM DAVIDSON INSTITUTE AT THE UNIVERSITY OF MICHIGAN BUSINESS SCHOOL

Explaining Gender Differences in Unemployment with Micro Data on Flows in Post-Communist Economies

By: Jana Stefanová Lauerová and Katherine Terrell

William Davidson Working Paper Number 506

September 2002 


\title{
EXPLAINING GENDER DIFFERENCES IN UNEMPLOYMENT WITH MICRO DATA ON FLOWS IN POST-COMMUNIST ECONOMIES
}

\author{
JANA STEFANOVÁ \\ LAUEROVÁ* \\ A C Nielsen Czech Republic \\ Prague, Czech Republic
}

\author{
KATHERINE TERRELL \\ University of Michigan \\ William Davidson Inst. \\ Ann Arbor, MI
}

September 2002

\begin{abstract}
Post-communist labor markets provide an interesting laboratory since unemployment rates grew from zero to double digits and gender differences began to vary greatly across these countries. We provide the first systematic analysis of the determinants of the gender unemployment gap in the Czech Republic using a method that decomposes unemployment rates into transition probabilities (flows) between labor market states, which we calculate using Labor Force Survey data. We extend the analysis to other post-communist economies by evaluating the flows available from existing studies with the decomposition framework. We further examine the flows in the Czech Republic by estimating gender-specific multinomial logit models to learn which factors (demographic, regional, cyclical) other than gender and marital status affect unemployment. We find that women's lower probability of exiting unemployment for a job explains the lion's share of the gender gap in the unemployment rates in the Czech Republic and the other post-communist countries for which studies exist. This is also the principal factor explaining married women's higher unemployment rates compared to married men in the Czech Republic. On the other hand, single men and women's rates are higher than married men and women's because they are twice as likely to lose/leave a job for unemployment. We find that age and education are systematically important in explaining flows of both men and women in all these economies, as it is in the more developed industrial economies. The less educated are more likely to be laid off or quit and less likely to find a job. Whereas younger individuals are more likely to be laid off or quit, they are also more likely to find a job.
\end{abstract}

JEL classification: C23, J64, J48, P20

Key Words: Unemployment, Gender, Transition Probabilities, Flow Analysis, Post-communist economies, Czech Republic

Acknowledgements: We would like to thank John Ham and Jan Svejnar for their useful comments as well as the participants of the Comparative Economics Seminar Series at the University of Michigan October, 2001 and an AEA Session at the ASSA meetings, Atlanta, January, 2002. Support from the National Science Foundation (Grants No. SES-921-3310 and SBR-951-2001) and the National Council for Soviet and Eurasian Research (Contract No. 812-32) is gratefully acknowledged.

*The views of this paper represent those of the author and her work carried out at the Universities of Michigan and Pittsburgh. They do not reflect the views of A C Nielson Czech Republic. 


\section{EXPLAINING GENDER DIFFERENCES IN UNEMPLOYMENT WITH MICRO DATA ON FLOWS IN POST-COMMUNIST ECONOMIES}

\section{Introduction}

The process of transition from centrally planned to market economies has required tremendous adjustment in the labor markets of Central and Eastern Europe (CEE) and the former Soviet Union (FSU). Under socialism, the economic environment was stable and job security was assured. There was no unemployment, little wage inequality, and very high labor force participation of both men and women. With the transition and the emergence of labor markets, many jobs were destroyed while new employment opportunities were created in small and medium enterprises. ${ }^{1}$ The economic and political transformations led an increasing number of people to leave the labor force and others to be unemployed.

This paper examines the relative impact of the transition to markets on men's vs. women's unemployment rates in these countries. We first provide an original analysis for the Czech Republic, where the unemployment rates for women have been consistently much higher than the rates for men since the beginning of the transition. We then use our findings and those from other studies to provide the first systematic analysis of the determinants of the gender unemployment gap in the post-communist economies.

Differences in any two groups' unemployment rates are obviously a result of differences in the frequency of job loss. However, unemployment rates can also differ because the one group faces greater difficulties in finding jobs or because these individuals move into and out of the labor force more frequently. Hence, a useful way to further our understanding of gender differences in unemployment rates is to analyze the differences between male and female transition probabilities (or flows) between any two of the principal labor market states: employment (E), unemployment (U), and out-of-the labor force (O). ${ }^{2}$ This enables us to pinpoint the driving forces behind the higher of the two unemployment rates: is it due to a lower probability of finding a job, a higher probability of leaving a job, or because women are more likely than men to enter unemployment from out-ofthe labor force and less likely to leave unemployment for out-of-the labor force? In this paper, we

\footnotetext{
${ }^{1}$ See Bilsen and Konings (1998), Faggio and Konings (2001) and Jurajda and Terrell (2001) for evidence of job destruction and job creation in the early years of the transition.

${ }^{2}$ In this paper we will use the terms flows and transition probabilities interchangeably.
} 
use quarterly Labor Force Survey data during the 1993-1996 period to provide the first calculations of these six flows for men and women by marital status, for the Czech Republic.

The literature estimating and analyzing transition probabilities across these labor market states in post-communist economies is substantial. ${ }^{3}$ However, there is very little research analyzing differences in men and women's unemployment rates in these economies. ${ }^{4}$ The second contribution of this paper is therefore to analyze the estimated flows by gender from this and other studies to establish if there is a systematic pattern in the determinants of gender differences in the postcommunist economies.

The third contribution of this paper is a microeconomic analysis of the determinants of women's and men's flows across labor market states in the Czech Republic. We estimate multinomial logit models to test whether or not single men and women continue to have significantly different transition probabilities than married men and women, once we control for other factors, such as age, education, location of residence and seasonal and cyclical factors. In the process we also identify which of these other factors affect the probability of leaving (or staying in) unemployment, employment or out-of-the labor force. In addition to its intrinsic value, knowledge of the magnitude of these flows is important for designing policies to reduce the incidence or duration of unemployment of different demographic groups.

\section{Overview of Women's Labor Force Participation and Unemployment in the Post-Communist Economies}

Women in socialist economies had among the highest labor force participation rates in the world. Some researchers expected that women would dramatically reduce their participation after the fall of communism, since the double burden of work and family had already become increasingly heavy before the change of regime. Paukert (1995) has shown that in the Central and

\footnotetext{
${ }^{3}$ See for example, Bellmann et al. (1995) for work on former East Germany; Gora and Lehmann (1995) for work on Poland; and Foley (1997) for work on Russia.

${ }^{4}$ Gender differences in unemployment may be noted as part of other gender differences in labor market outcomes in other studies, but it is not specifically analyzed (see for e.g., Brainerd, 2000; Orazem and Vodopivec, 1995; Nesporova, 1998). For the Czech Republic only one other study (Ham, Svejnar and Terrell, 1999) explicitly examines differences in men and women's unemployment rates. This study estimates hazard models to analyze exits out of unemployment to jobs using administrative data from the unemployment offices during the first two years of transition. Although it sheds light on the differences in this one flow, it is only part of the explanation for gender differences in unemployment.
} 
East European countries there were significant declines in women's labor force participation rates (LFPRs) pre- and post-transition up until 1994 (see Table 1). However, her results indicate that in early transition the withdrawal of women was only slightly greater than that of men in many of these economies. Moreover, as partially seen from the differences in the two measures of LFPRs in Table 1, women's withdrawal was highest among women in older age groups, not among women in ages more likely to have small children. This age pattern was also found for men since early retirement was encouraged by government measures destined to combat unemployment in the early years of transition. In hindsight, it seems that the large reductions in the wage levels in all of these post-communist countries may have prevented women from leaving the labor force at a faster pace.

In the Czech Republic the decline in the LFPRs continued at a slower pace for women but came virtually to a halt for men from 1994 to 1996 (see Table 2). In particular, there was a 1.1 percentage point decline in women's LFPRs and 0.5 percentage point decline in men's LFPRs between 1Q94 and 1Q96. ${ }^{5}$ However, contrary to Paukert's (1995) findings for the 19891994 period, most of the decline for both men and women is in the youngest (15-19 year) age group, while the older generation has increased its participation rate over this period. ${ }^{6}$ In addition, LFPRs of women ages 20-39 continue to have significant declines over the period whereas LFPRs for men in this age range are only falling for the 20-24 age group. As Chase (1998) notes, much of this decrease in women's LFPRs results from changing costs of childcare, which became more expensive after the end of the communist policies.

What about unemployment rates? As seen in Table 3, by 1992 unemployment rates had risen to double digits in most of the post-communist economies and they have remained at fairly high levels since then. The gender difference in unemployment in the Czech Republic is striking as women's unemployment rates immediately became higher than men's rates, and remained higher over the first ten years of the transition period. As seen in Figure 1, which uses data from the Czech Labor Force Surveys first implemented in 1993, women's rates were higher in every

\footnotetext{
${ }^{5}$ The quarters correspond to the following months: Q1 (December to February), Q2 (March to May), Q3 (June to August), and Q4 (September to November).

${ }^{6}$ This trend is consistent with the increasing secondary school and university enrollment rates in the Czech Republic during the transition. Enrollment rates for secondary school have risen from $83.7 \%$ in $1989 / 90$ to $95.9 \%$ in $1996 / 97$ while enrollments in university education have risen from 17.15 to $20.0 \%$ over the same period (numbers provided by Ministry of Education).
} 
quarter of 1993-1996. The average unemployment rate over these 14 quarters was 2.9 percent for men and 4.2 percent for women. We also note that the unemployment rates for single individuals are considerably higher than those for married and hence deserve further inspection. Moreover, the gender gap is not as large between single men and single women as it is for married men and married women ( 0.3 percent vs. 1.6 percent, respectively).

Unemployment rates by gender for eight former socialist economies, presented in Table 3, indicate a definite, time-consistent pattern of gender differences within each country, but a mixed pattern across the countries. ${ }^{7}$ Women have been affected more than men by unemployment in the Czech Republic, Poland, and Slovakia. However, women's rates are very similar to men's in Bulgaria and Russia, somewhat lower in Slovenia and the Ukraine, and substantially lower in Hungary.

In sum, the data on LFPR and unemployment rates from several former socialist countries indicate that the transition has not systematically left more women than men without work. The ratio of female to male unemployment rates varies tremendously across the post-communist countries. However, in the Czech Republic, women's unemployment rates have remained about $50 \%$ higher than men's throughout the period under study. In the following sections, we focus on explaining this persistent gap, beginning with a description of our data and methodology.

\section{Data and Methodology}

The micro data set used for our analysis is the Czech Republic's Labor Force Survey (LFS), collected on a quarterly basis by the Czech Statistical Office. The LFS provides information on approximately 28,000 randomly selected households, or nearly $1 \%$ of the population of the Czech Republic and is representative of the nine major regions. The LFS only began being conducted in the second quarter of 1993 (2Q93) and since we do not have comparable data for the earlier period of transition, we do not analyze unemployment rates and flows during 1990-1992. However, we have data from $2 \mathrm{Q} 93$ to $4 \mathrm{Q} 96$, making it is possible to analyze fourteen consecutive quarters of

\footnotetext{
${ }^{7}$ We note that since Labor Force Surveys were not conducted prior to 1993 in any of these postcommunist countries, the unemployment rates for earlier periods are calculated with administrative data from the unemployment offices. Rates calculated from unemployment registry data are not strictly comparable to those calculated from Labor Force Surveys, largely because they rely on individuals signing up for unemployment benefits. Nevertheless, we can be comfortable with statements made about general gender differences within each series over time.
} 
data.

In defining the three main states of the labor market, we use the internationally accepted International Labor Organization (ILO) definitions: The employed comprise all people aged 15 or more who during the reference week were in paid employment or self-employment for at least one hour. The one deviation from the ILO definition is that the employed here also include women on maternity leave, a rule followed by the Czech Statistical Office. The unemployed comprises all people aged 15 or older who during the reference week fulfilled all of the following conditions: (i) were without work; (ii) were actively seeking work and (iii) were currently available for work. Those out-of-the labor force are the remaining people ages 15 or older.

Summary statistics of the data on these individuals are found in appendix Table A1. The table provides means and their standard deviations (over 15 quarters) of the variables used in the analysis by labor market state of origin: employment, unemployment and out-of-the labor force.

\subsection{Gross Flow Methodology:}

The change from one state of the labor market to another can be viewed as a dynamic process, where time is treated as a discrete variable and the dynamics are given by a system of difference equations. The process under study in our case can be described as a Markov Process with three (stationary) states, represented by the fraction of the working population that is employed (ER), unemployed (UR) and out-of-the labor force (OR) and by the transition probabilities of moving from state $\mathrm{k}$ in period $\mathrm{t}$ to state $\mathrm{j}$ in period $\mathrm{t}+1\left(\mathrm{P}_{\mathrm{kj}}\right)$. We use the following notation: $\mathrm{P}_{\mathrm{EE}}$ is the transition probability of staying employed between time $t$ and $t+1 ; \mathrm{P}_{\mathrm{EU}}$ is the probability of leaving employment for unemployment, etc. In matrix notation we have:

$$
s(t+1)=T^{-1} \bullet s(t)
$$

where the state variables are arranged in a vector

$$
s(t)=\left[\begin{array}{c}
E R(t) \\
U R(t) \\
O R(t)
\end{array}\right] ; s(t+1)=\left[\begin{array}{c}
E R(t+1) \\
U R(t+1) \\
O R(t+1)
\end{array}\right],
$$

and the transition probabilities are arranged in the matrix 


$$
T=\left[\begin{array}{lll}
P_{E E}, & P_{E U}, & P_{E O} \\
P_{U E}, & P_{U U}, & P_{U O} \\
P_{O E}, & P_{O U}, & P_{O O}
\end{array}\right] .
$$

The gross probability of transition from state $k$ to state $j$ is given as:

$$
P_{k j}=\frac{\text { Flow }_{k j}}{\text { Stock }_{k}}, \quad k, j=\{e, u, o\}
$$

where, Flow $_{k j}$ is the number of individuals in state $k$ at time $t$ who are in state $j$ at time $t+1$ and Stock $_{k}$ is the original stock of individuals in state $k$ at time $t^{8}$ The time interval used in this analysis is one quarter.

We will compare gross transition probabilities first for men and women and then for single vs. married men and women to understand the source of their unemployment. The following equation, derived by Marston (1976), illustrates how the unemployment rate (UR) can be expressed as a function of transition probabilities between the three labor market states if the labor market is in a "steady state":"

$$
U R=\frac{1}{1+\left[\frac{\left(P_{O E}+P_{O U}\right) P_{U E}+P_{O E} P_{U O}}{\left(P_{O E}+P_{O U}\right) P_{E U}+P_{O U} P_{E O}}\right]}
$$

The labor market can be considered to be in a steady state when the flows into and out of employment are equal

$$
\mathrm{P}_{\mathrm{UE}} \mathrm{U}+\mathrm{P}_{\mathrm{OE}} \mathrm{O}=\left(\mathrm{P}_{\mathrm{EU}}+\mathrm{P}_{\mathrm{EO}}\right) \mathrm{E}
$$

as are the flows into and out of unemployment

$$
\mathrm{P}_{\mathrm{EU}} \mathrm{E}+\mathrm{P}_{\mathrm{OU}} \mathrm{O}=\left(\mathrm{P}_{\mathrm{UE}}+\mathrm{P}_{\mathrm{UO}}\right) \mathrm{U}
$$

It is difficult to argue that the Czech labor market is in a steady state since it has been responding to enormous structural changes. Nevertheless, men's (women's) average unemployment rate for the

\footnotetext{
${ }^{8}$ Note that we are assuming that a Markov process governs the movements, i.e. that the probability of transition depends only on the last occupied state.
} 
period calculated by equation (5), using the flows found in appendix Table A1, is quite similar to the rate calculated from the conventional stock formula of $U /(U+E)$, using the average number unemployed and employed from data in appendix Table A1. The two rates are 2.85 vs. 2.88, respectively for men and 4.38 vs. 4.21 , respectively for women.

Equation (5) makes it clear that increases in $P_{U E}, P_{U O}$, and $P_{O E}$ lead to decreases in the unemployment rate, while increases in $P_{E U}, P_{E O}$, and $P_{O U}$ lead to increases in the UR. We will use these relationships to pinpoint which flows are driving the differences between men and women's unemployment rates. Knowing which flows are important is useful in helping design the correct policies for reducing the unemployment rate of a given group. Moreover, the initial values of the group's labor market transition probabilities can serve as a baseline in evaluating the effectiveness of a given policy.

\subsection{Multinomial Logit Analysis}

The univariate associations between labor market transition rates and gender and marital status, respectively, may be due to differences in men's and women's level of education, differences in their responses by education, or some other variables (e.g., age). Hence, to check the robustness of the basic findings, and to assess the effect of these other factors, we estimate a multivariate model of the transition probabilities. In particular, using multinomial logit analysis we estimate the probability of individual $i$ leaving one labor market state for another, conditional on being in one state as:

$$
\operatorname{Prob}\left(Y_{i t}=j \mid Y_{i t-1}=k\right)=\frac{\exp \left(Z_{i}^{\prime} \beta_{k}\right)}{\sum_{k} \exp \left(Z_{i}^{\prime} \beta_{k}\right)}
$$

where $j, k=1,2,3$ are the three labor market states. State $k$ is the state of origin and state $j$ is the destination. The subscript $i$ denotes the individual and $\mathrm{Z}_{i j k}$ are the characteristics of the $i$-th individual moving from state $k$ to state $j$. Explanatory variables included in the $\mathrm{Z}$ matrix are: Age -- dummy variables for ten-year age groups, beginning with 15-24 as the base; educational attainment -- dummy variables for four levels of education: (i) junior high school (the base), (ii)

\footnotetext{
${ }^{9}$ For an analysis of male-female unemployment rates in the U.S. that uses Marston's (1976) method, see DeBoer and Seebor (1989).
} 
apprenticeship with or without the general exam, (iii) high school and (iv) university; ${ }^{10}$ marital status - married is the base; region of residence (and work) -- six dummy variables, Prague is the base; ${ }^{11}$ quarterly and annual dummies to capture changes in seasonal and annual changes in demand and other shocks. ${ }^{12}$

The log-likelihood function that is being optimized has the following form

$$
\ln L=\sum_{i} \sum_{j} D_{i j} \ln \left[\operatorname{Prob}\left(Y_{i t}=j \mid Y_{i t-1}=k\right)\right]
$$

where $D_{i j}$ is equal to 1 if an individual $i$ is moving from state $k$ to state $j$ and equal to 0 otherwise.

The interpretation of the logit coefficients is not straightforward and is best thought of as capturing the relative likelihood of being in each state. The marginal impact of a single explanatory variable, $\mathrm{z}_{i}$, on the transition probability to state $j, P_{j}$, is given by

$$
\frac{d P_{j}}{d z_{i}}=P_{j}\left[b_{j}-\sum_{k} P_{k} b_{k}\right],
$$

where $b$ is the appropriate element of the parameter vector $\beta$. Hence, the magnitude of a variable's influence depends on the choice of $P_{j}$. In order to aid our understanding of the relative impact of various factors, we present the estimates of marginal impacts evaluated at the sample mean transition probabilities.

\footnotetext{
${ }^{10}$ Human capital theory would predict that the less educated are more likely to be laid off. However, it is not clear what the link should be between education and finding a job. Since the quasi-fixed costs of hiring and training more educated workers are greater than those for less educated workers, it would seem that that the unskilled would be more readily hired. However, if employment decreases, lower educated workers compete for scarce jobs with higher educated people and employers might raise their hiring standards giving more educated workers more chances to be hired. Moreover, more educated workers are thought to be more mobile and more flexible in the labor market. Finally, the more educated may take a less educated job while looking for more suitable employment. For a review of potential gender differences in the relationship between turnover and education, see Royalty (1998).

11 Transition probabilities may differ across regions as they have different demand conditions and economic structures. For example, Moravia, a highly agricultural area, and Northern Bohemia, dependent on the coal mining industry, have had the highest unemployment rates throughout the transition.

${ }^{12}$ We would have liked to have information on wages but this variable is not available in the Czech Labor Force Surveys in the period under study.
} 


\section{Empirical Results for Gross Flows}

In this section, we describe the averages, trends and seasonal patterns in the gross flows by gender and marital status. Table 4 contains the quarterly transition probabilities, averaged over 14 quarters. The differences between these mean probabilities are tested for statistical significance in order to draw conclusions about which flows are driving the gender and marital status gap in the unemployment rates. In addition, we briefly describe the trends and seasonal patterns in these flows during the 2Q93-4Q96 period. $^{13}$

\subsection{Outflows from employment}

The probability that a person remains employed from one quarter to the next $\left(\mathrm{P}_{\mathrm{EE}}\right)$ is surprisingly high over this period, given the amount of structural change the economy was experiencing in the first part of this period. On average, the quarterly probability is 98.3 percent for men and 97.8 percent for women (row one of Table 4) and it is comparable to similarly calculated probabilities for the U.S. The gender difference is small (0.5) but statistically significant. As seen in column three, first three rows of Table 4, one-fourth of this difference is due to the higher probability that women leave employment to go out-of-the labor force $\left(\mathrm{P}_{\mathrm{EO}}\right)$ and the remaining fourth is due to the higher probability that women leave employment for unemployment $\left(\mathrm{P}_{\mathrm{EU}}\right)$.

The comparison of these transition probabilities for married men and married women vs. single men and single women reveals that the gender gap in $\mathrm{P}_{\mathrm{EE}}$ is greater for married individuals than for non-married (0.6 vs. 0.1, respectively). Both married and single men's higher probability of remaining employed is again due primarily to the fact that married and single women have higher probability of leaving the labor force. To be precise, all of the difference between single men and women's $\mathrm{P}_{\mathrm{EE}}$ 's is due to single women's higher $\mathrm{P}_{\mathrm{EO}}$ 's, while two-thirds of the difference between married men and women's $\mathrm{P}_{\mathrm{EE}}$ 's is due to married women's higher $\mathrm{P}_{\mathrm{EO}}$ 's.

An examination of the quarterly transition probabilities (not shown here) show that the $\mathrm{P}_{\mathrm{EE}}$ 's for men are higher than those for women throughout the period and the trends are rising for both men and women, reflecting the slowing down of structural changes and improvement in the economy. Conversely, the transition probabilities from employment to both unemployment and out-

\footnotetext{
13 The graphs are available from the authors upon request. We do present the differences (and their standard errors) between men's and women's quarterly transition probabilities in appendix Table A2. The same information for the transition probabilities by gender and marital status is presented in appendix Table A3.
} 
of-the labor force were higher for women throughout and exhibit a falling trend for both men and women. A closer examination of these trends for married vs. single men and women reveals that married people are more likely to stay on the job than single people. The rates are consistently higher for married men compared to married women and almost identical for single men and women. Single men and women are far more likely than married men and women to be laid off or quit, with the difference between single people being not significant; while the rate for married women is always higher than for married men. For most of the period women (especially single women) are more likely than men to leave the labor force. There is some cyclical behavior in the trend of $\mathrm{P}_{\mathrm{EO}}$ 's for single women, with peaks in the transitions in the third to the fourth quarter (Q3Q4) of each year.

\subsection{Outflows from unemployment}

On average, the probability of remaining unemployed from one quarter to the next is higher for women, especially married women (Table 4). Plots of the $P_{U U}$ for these fifteen quarters show that women's rates are higher until the period between the end of 1994 and the end of 1995 (as the economy was growing most rapidly) when women's rates become quite similar to, and sometimes even lower than, the rates for men. As in all countries, there is a cyclical pattern in these flows. Women have shorter durations of unemployment (i.e., lower $P_{U U}$ ) during the boom years. There are also seasonal changes in these flows where peaks (especially for women) in $\mathrm{P}_{\mathrm{UE}}$ are between $\mathrm{Q} 1$ and Q2 and between Q3 and Q4. In Section 6.2, we test for the significance of seasonal and cyclical effects, once we hold other factors constant.

As we will show to be important in the next section, the average $P_{U E}$ is significantly higher for men (27.3 percent) than for women (21.3 percent). Moreover, women tend to leave unemployment for out-of-the labor force more than men do (the average $P_{U O}$ is 6.7 percent for men and 7.5 percent for women). The plots in $P_{U O}$ show no trend, but there is a cyclical pattern for women with peaks occurring between Q1 and Q2. When the flows out of unemployment are examined by marital status, it becomes clear that this distinction is very important for women but not so significant for men. Most important is the finding that the transition from unemployment to a job $\left(\mathrm{P}_{\mathrm{UE}}\right)$ is lowest for married women (on average 21.3 percent) among the four groups. (The average transition probabilities from $\mathrm{U}$ to $\mathrm{E}$ for single women are not statistically different from those for single men -25.7 vs. 26.1, respectively -- and married men's are the highest). Second, we find only married women have a significantly different and higher $P_{U O}$. (Single women tend to leave for out-of-the 
labor force at approximately the same rate as single or married men.)

\subsection{Outflows from out-of-labor force}

As shown in Table 4, women are more likely than men to remain out-of-the labor force but the difference is not large (on average 97.8 percent vs. 97.0 percent). Men are far more likely to find a job from this state ( 2.5 percent vs. 1.7 percent). The analysis of transitions by marital status indicates that single men behave differently than the other three groups (least likely to stay out-ofthe labor force and most likely to leave for a job). The plots indicate very interesting cyclical patterns for the two transition probabilities from the out-of-the labor force state: The $P_{O E}$ clearly rises for the transitions from the $3 \mathrm{Q}$ to $4 \mathrm{Q}$ of every year, while the $P_{O U}$ 's clearly rise the period earlier (2Q to $3 \mathrm{Q})$.

Overall, the data show that there are significant differences between men and women's average flows and that barring a few exceptions, these differences are persistent over time. We also note that an individual's marital status also plays a role in determining the size of these flows. In the next section, these average flows are analyzed using Marston's decomposition equation.

\section{Explaining Differences in the Female-Male Unemployment Rates}

\subsection{Results for the Czech Republic}

As noted in the discussion of equation (5), in order to explain the gender gap in the unemployment rates we must examine the differences among all six transition probabilities for men and women, rather than just flows in and out of unemployment. We begin with $\mathrm{P}_{\mathrm{UE}}, \mathrm{P}_{\mathrm{UO}}$, and $\mathrm{P}_{\mathrm{OE}}$, each of which is negatively correlated with the unemployment rate. Higher values of any of these three transition probabilities will lower the unemployment rates for a given group. Hence, higher values for men relative to women mean that these transition probabilities are driving down men's unemployment rates more than women's and therefore increasing the gap. As seen in Table 4, women's higher average unemployment rate is being driven largely by differences in the probability of exit from unemployment to a job $\left(\mathrm{P}_{\mathrm{UE}}\right)$, which is 3.5 percentage points higher for men than for women. The differences in the other two probabilities, $\mathrm{P}_{\mathrm{UO}}$ and $\mathrm{P}_{\mathrm{OE}}$, are smaller and effectively cancel each other out. The -0.72 male-female difference in $\mathrm{P}_{\mathrm{UO}}$ reduces the gap between men and women's unemployment rates (by lowering women's rates more than men's), whereas the 0.76 difference between men and women's $\mathrm{P}_{\mathrm{OE}}$ increases the gap. 
Hence women's unemployment rates are being reduced relative to men's via non-participation rather than through increased employment.

Turning to the remaining three probabilities, we note the symmetric but reversed relationship: Increases in $\mathrm{P}_{\mathrm{EU}}, \mathrm{P}_{\mathrm{EO}}$ and $\mathrm{P}_{\mathrm{OU}}$ increase the unemployment rate of a group. If any of these three transition probabilities is higher for men than women, it increases men's unemployment rates relative to women, and hence reduces the differential between them. As seen in Table 4, all three probabilities are lower for men than women and hence contribute to increasing the gender gap. Women are more likely to exit a job for either unemployment or outof-the labor force and are more likely to enter unemployment from out-of-the labor force. However, since the differences in these three flows are all small, as are differences in $\mathrm{P}_{\mathrm{UO}}$ and $\mathrm{P}_{\mathrm{OE}}$, the combined differences in these five probabilities do not account for as much as the gender difference in $\mathrm{P}_{\mathrm{UE}}$ in explaining the difference in unemployment rates between men and women.

When we control for marital status, we obtain a number of similar and some different results. As may be seen from Table 4, the difference in the $\mathrm{P}_{\mathrm{UE}}$ flows is again the most important determinant of the difference between married women and married men: women's probability of getting a job from unemployment is 6.0 percentage points lower than a married man's probability (column 6). However, married women also have a much higher $\mathrm{P}_{\mathrm{UO}}$ (in fact, highest among the four groups by gender and marital status), which puts downward pressure on their unemployment rate relative to the others. The main factor explaining single women's higher unemployment rate compared to single men is the flow from out-of-the labor force into employment $\left(\mathrm{P}_{\mathrm{OE}}\right)$, which is 2.1 percentage points lower for single women. The difference in single men and women's $\mathrm{P}_{\mathrm{EU}}$ is not significant and whereas the differences in the other four transition probabilities are significant, they are relatively small.

As we noted above, where the difference in unemployment rates is most pronounced is between single and married individuals. Evaluating differences in marital status, holding gender constant, we find that a very different factor at play: The probability of (voluntarily or involuntarily) leaving a job for unemployment $\left(\mathrm{P}_{\mathrm{EU}}\right)$ is twice as large for single individuals than for the married ones. In addition, we find single men have much lower $\mathrm{P}_{\mathrm{UE}}$ than married men, which would help explain their higher unemployment rate. The higher unemployment rate of single women is also partially explained by their much lower $\mathrm{P}_{\mathrm{EU}}$, compared to married women. 
We conclude this section by emphasizing that the higher unemployment rate of women than men in the Czech Republic is being driven primarily by the fact that women, especially married ones, are less likely than men to leave unemployment for a job $\left(\mathrm{P}_{\mathrm{UE}}\right)$ in a given quarter. ${ }^{14}$ What explains the much higher unemployment rates of single individuals compared to married ones? The only single factor is the higher probability of leaving a job for unemployment $\left(\mathrm{P}_{\mathrm{EU}}\right)$, which is almost double for single men and women as compared to married individuals. In addition, single men's higher unemployment rate compared to married men is explained by differences in $\mathrm{P}_{\mathrm{UE}}$ which is lower for single men; the most important additional factor driving the gap between married and single women is the difference in $\mathrm{P}_{\mathrm{UO}}$, which is lower for single women (driving up their unemployment rates).

\subsection{Results for East Germany, Poland and Russia}

In this section, we assess the extent to which the flows that we identified as being important in the Czech Republic are important more generally in explaining differences in the unemployment rates of men and women in other post-communist economies. As may be seen from Table 5, we are able to apply equation (5) to transition probabilities from East Germany, Poland and Russia and generate comparative calculations for the Czech Republic and these three transition economies. ${ }^{15}$

Using 1990-91 flow data from East Germany (provided by Bellmann et al., 1995), we find that the higher unemployment rate for East German women is caused to a significant extent by their lower probability of leaving unemployment for a job $\left(\mathrm{P}_{\mathrm{UE}}=31.5\right.$ percent as compared to 39.9 percent for men) but also their higher probability of becoming unemployed from employment $\left(\mathrm{P}_{\mathrm{EU}}\right.$ $=13.2$ percent as compared to 5.7 percent for men). Again, as in the Czech Republic, women tend to leave the labor force from unemployment to a much greater extent than men (which is often considered as the "discouraged worker" effect).

Analyzing Gora and Lehmann's (1995) annual flows by gender for 1993-94 from the Polish

\footnotetext{
${ }^{14}$ Although less important, the higher unemployment rates of women are also arising from women's higher probability of loosing or quitting their jobs to become unemployed or leave the labor force $\left(\mathrm{P}_{\mathrm{EU}}\right.$ or $\left.\mathrm{P}_{\mathrm{EO}}\right)$ and higher likelihood of flowing from out-of-the labor force to unemployment $\left(\mathrm{P}_{\mathrm{OU}}\right)$ and lower probability of flowing from out-of-the labor force to employment $\left(\mathrm{P}_{\mathrm{OE}}\right)$.

15 Unfortunately, these studies do not have information on marital status so we are restricted to comparisons of men and women.
} 
Labor Force Survey with the decomposition analysis, we also find that the difference between women and men's outflows from unemployment $\left(\mathrm{P}_{\mathrm{UE}}=29.6\right.$ percent for women vs. 41.8 percent for men) is the most important factor explaining women's 3 percentage-point higher unemployment in this period. We note that women in Poland also tend to exhibit discouraged worker effects, which lowers their unemployment rate (but in a nonproductive way).

Foley (1997) created flow figures for the Russian labor markets using annual panels of data from the RLMS (Russian Longitudinal Monitoring Survey) for 1992-3 and 1995-6. Although the difference in men's and women's unemployment rates are relatively small in Russia (and men's rates are higher), we find once again that women are less likely to leave unemployment for employment (with about a 3 percentage point difference). What appears to be lowering women's unemployment rate relative to men's is the far higher probability (on the order of 10 percentage points) of leaving the labor force from unemployment $\left(\mathrm{P}_{\mathrm{UO}}\right)$.

In sum, the findings in Table 5 and our earlier analysis indicate that women's substantially lower probability of transition from unemployment to a job $\left(\mathrm{P}_{\mathrm{UE}}\right)$ is one of the most important factors that raises women's unemployment rate (relative to that of men) in the Czech Republic, East Germany, Poland, and Russia. In all countries, except for East Germany, women's higher rate of exit from the labor force from unemployment $\left(\mathrm{P}_{\mathrm{UO}}\right)$ tends to lower their unemployment rates relative to men. Whereas women in the Czech Republic and East Germany are more likely to leave/lose their job and go into unemployment $\left(\mathrm{P}_{\mathrm{EU}}\right)$, women in Poland and Russia are less likely than men to leave or be laid off from a job. Hence, there is a clear pattern that gender differences in $\mathrm{P}_{\mathrm{UE}}$ and $\mathrm{P}_{\mathrm{UO}}$ are the most important factors driving the male-female unemployment rate differentials in these countries.

\section{Multinomial Logit Estimates}

We next pool the 14 quarters of the Czech Labor Force Survey data and estimate multinomial logit models separately for men and women to examine the robustness of the differences in the flows of single vs. married men and women when we take into account other potential explanatory variables that may affect these flows. Table A1 in the appendix provides the summary statistics (means over the 14 quarters) for the variables by state of origin: employment, unemployment and out-of-labor force. The estimated coefficients of the multinomial logits are presented separately by state of origin: Table 6, exits from employment; Table 7, exits from unemployment; and Table 8, 
exits from out-of-labor force. We begin with a description of the relationship between the transition probabilities and other demographic and time varying factors in Section 6.1 and then describe their ceteris paribus correlation with marital status in Section 6.2.

\subsection{Other factors affecting flows}

The coefficients and standard errors in Tables 6,7 and 8 indicate that there are significant differences in the flows by age, education and most region and time dummies. We look for patterns in the relationships between flows and the demographic and time varying variables using the same framework as above (i.e., equation 5). ${ }^{16}$

With respect to age, we find that young men and women (less than 35 years of age) are more likely to become unemployed (have higher $\mathrm{P}_{\mathrm{EU}}$ and $\mathrm{P}_{\mathrm{OU}}$ ) but, they are also more likely to get a job (higher $\mathrm{P}_{\mathrm{UE}}$ and $\mathrm{P}_{\mathrm{OE}}$ ) which lowers their unemployment rate relative to older people. Hence, the incidence of unemployment of young people is high but duration is relatively low. Comparisons of the marginal effects of each age group for men vs. women indicate that they are similar (see for e.g., transition from employment to unemployment in columns 2 and 4 of Table 6) with some exceptions in $\mathrm{P}_{\mathrm{UE}}$ and $\mathrm{P}_{\mathrm{OU}}$, which do not vary with age for women to the extent that they do for men. We conclude that the effect of age on flows is very similar for men and women

Regarding education, we find that the less educated men and women are more likely to leave employment for the other two states (have higher $\mathrm{P}_{\mathrm{EU}}$ and $\mathrm{P}_{\mathrm{EO}}$ ) and less likely to enter employment (lower $\mathrm{P}_{\mathrm{UE}}$ and $\mathrm{P}_{\mathrm{OE}}$ ), all of which increase their unemployment rate relative to the more educated. Moreover, this is a monotonic relationship in that the first (latter) two probabilities decrease (increase) with each higher level of education (e.g., the probability of leaving a job for unemployment is highest for the elementary school leavers and falls continuously for each of the three higher levels of schooling). The two flows that tend to lower the unemployment rates of the less educated are the higher flows between unemployment and out-of-the labor force $\left(\mathrm{P}_{\mathrm{UO}}\right.$ and $\left.\mathrm{P}_{\mathrm{OU}}\right)$. We also find that the marginal effects of each level of education on the flows out of employment, unemployment and out-of-the labor force are very similar for men and women, with two exceptions: 1) university educated women are much less likely to leave unemployment than university educated men, ceteris paribus; 2) women with high school and university education are much more likely

\footnotetext{
${ }^{16}$ Given that the regional variables are included primarily as controls for the employment structure and they lack comparability with other studies, we do not describe the coefficients on these variables.
} 
than men with the same education to move from out-the-labor-force into the labor force (either to a job or unemployment).

What about seasonal and cyclical effects? There is a substantial literature testing whether or not men's unemployment rates rise more rapidly than women's in a recession or visa versa ${ }^{17}$ It is often argued that marginal groups in the labor market tend to find jobs at a higher rate in upswings and loose jobs more easily in recessions. If women are considered marginal workers, then their unemployment rates would rise more than men's during a recession and fall more rapidly in an upswing. On the other hand, if women are more easily discouraged (i.e., leave the labor force) than men in a recession, this could decrease their unemployment relative to men. Of course, the relative rates also depend on whether more men/women are employed in the industries that are more sensitive to seasonal or cyclical swings. We find that women have more seasonal variability than men. For example, women's probabilities of leaving a job for unemployment $\left(\mathrm{P}_{\mathrm{EU}}\right)$, leaving employment for out-of-the labor force $\left(\mathrm{P}_{\mathrm{EO}}\right)$ or leaving unemployment for a job $\left(\mathrm{P}_{\mathrm{UE}}\right)$ are more sensitive than men's to seasonal variation. ${ }^{18}$ On the other hand, their responses to annual changes in the economy are quite similar. The economy moved out from the trough of the recession in 1993 with continued growth from 1994 to 1996 . This upswing is reflected in declining flows from jobs to unemployment $\left(\mathrm{P}_{\mathrm{EU}}\right)$ and to out-of-the labor force $\left(\mathrm{P}_{\mathrm{EO}}\right)$ from 1993-1996 for both men and women, and at similar rates. Interestingly, for both men and women, there is no trend in the probabilities of entering jobs from unemployment $\left(\mathrm{P}_{\mathrm{UE}}\right)$ or in leaving unemployment to go out-of-the labor force $\left(\mathrm{P}_{\mathrm{UO}}\right)$ over these years. However, individuals were less likely to find jobs from out-of-the labor force at a higher rate $\left(\mathrm{P}_{\mathrm{OE}}\right)$ as the years passed, and the likelihood became even smaller for women. Hence, women were less likely to be hired from out-of-the labor force than men over time but the difference in their probabilities of hire from unemployment did not change over time for either gender.

\subsection{Marital Status}

Once we control for demographic and other factors which may be correlated with the impact of

\footnotetext{
${ }^{17}$ See for example, studies by DeBoer and Seeborg (1989) using U.S. data, and Myatt and Murrell (1990), using Canadian data.

${ }^{18}$ We can also see from these coefficients that higher seasonal unemployment rates in the first quarter of every year are the result of a higher probability in that quarter over the other three quarters that individuals leave/lose jobs and become unemployed $\left(\mathrm{P}_{\mathrm{EU}}\right)$ and lower likelihood of leaving unemployment for a job $\left(\mathrm{P}_{\mathrm{UE}}\right)$ or to leave the labor force $\left(\mathrm{P}_{\mathrm{UO}}\right)$.
} 
marital status, do we still find significant differences in the flows that were found to make a difference in the gross flow analysis? The answer is yes for men: the flows we found to be important in pushing up the single men's unemployment rates relative to married men's -- $\mathrm{P}_{\mathrm{UE}}$ and $\mathrm{P}_{\mathrm{OE}}$-- continue to be significantly different. However, whereas the marginal effect of single men's lower $\mathrm{P}_{\mathrm{UE}}$ continues to be very large, the difference between single and married men's $\mathrm{P}_{\mathrm{OE}}$ becomes smaller. Hence, the difference in $\mathrm{P}_{\mathrm{UE}}$ becomes even more important in explaining the difference between single men and married men's unemployment rates, after controlling for age, education and location of work (local labor market). The differences between two other flows, which were not all that important in the gross analysis $\left(\mathrm{P}_{\mathrm{UO}}\right.$ and $\left.\mathrm{P}_{\mathrm{OU}}\right)$, become insignificant.

The answer for women is more complex. One flow that was found to raise single women's unemployment rates relative to married women $-\mathrm{P}_{\mathrm{EU}}$ - is significant; however the difference between single and married women's $\mathrm{P}_{\mathrm{UO}}$, which was important in the gross flows, is no longer significant. The flow which becomes more important in explaining higher unemployment among single women is $\mathrm{P}_{\mathrm{OE}}$ : single women are less likely to get a job out-of-the labor force compared to married women. Hence, once we control for other demographic and seasonal factors, the differences between single and married women's flows change significantly.

\section{Final Remarks}

Our study is motivated by the striking fact that women's unemployment rates in the Czech Republic have been persistently higher than those of men throughout the first 10 years of the transition to markets and that the rates of single men and women are substantially higher than their married counterparts. We provide the first systematic analysis of the determinants of the gender unemployment gap in the Post-Communist countries. We use Marston's method to decompose unemployment rates into transition probabilities between labor market states, which we calculate for the Czech Republic using Labor Force Survey data. We extend the analysis to other postcommunist economies by evaluating the flows available from existing studies with the decomposition framework. Finally, we further examine the flows in the Czech Republic by estimating gender-specific multinomial logit models to learn whether marital status is still significant after controlling for other determinants (demographic, regional, cyclical).

With respect to the gross flow analysis, we find that the principal reason women's unemployment rates are higher than men's in the Czech Republic is not because women are more 
likely to enter unemployment but rather because the probability that women leave unemployment for a job $\left(\mathrm{P}_{\mathrm{UE}}\right)$ in any given quarter is far lower than men's. We find that women's lower outflow from unemployment to a job are is a major determinant of gender differences in unemployment in East Germany, Poland and Russia. In the Czech Republic we are able to identify that it is married women who are particularly unlikely to leave unemployment for a job in any given quarter. For single individuals, the most important factor explaining their higher unemployment rates is that they are more likely than married individuals to leave (quit or lose) their jobs for unemployment $\left(\mathrm{P}_{\mathrm{EU}}\right)$. The finding of higher $\mathrm{P}_{\mathrm{EU}}$ for single vs. married men and women is robust to controls for other factors that affect these flows in the multinomial analysis. However, we also find that the difference between single and married women's probability of finding a job from out-of-the labor force ( $\left.\mathrm{P}_{\mathrm{OE}}\right)$ proves to be important in explaining their unemployment gap once age, education, region and time varying variables are introduced into the equation.

The multinomial analysis also allows identification of the flows that are important in explaining differences in unemployment rates by age and education groups. We find that for both men and women, the less educated are more likely to be laid off or quit (higher $\mathrm{P}_{\mathrm{EU}}$ and $\mathrm{P}_{\mathrm{EO}}$ ) and less likely to find a job (higher $\mathrm{P}_{\mathrm{UE}}$ and $\mathrm{P}_{\mathrm{OE}}$ ). Hence the less educated tend to have a higher incidence of unemployment and longer spells. Younger men and women (ages 15-34) are more likely to be laid off or quit (higher $\mathrm{P}_{\mathrm{EU}}$ and $\mathrm{P}_{\mathrm{EO}}$ ) but they are also more likely to find a job (higher $\mathrm{P}_{\mathrm{UE}}$ and $\mathrm{P}_{\mathrm{OE}}$ ), as is characteristic in most market economies. Hence whereas their incidence of unemployment may be higher, the duration of their spells would be shorter for younger (15-34) compared to older (35+). The direction of the effects of age and education are similar on men and women's flows, although the magnitude may differ. With respect to seasonal and cyclical effects, we find women's flows are more sensitive to seasonal (quarterly) variations than men's flows but the marginal effects of the annual dummies are similar, indicating that the difference between men and women's flows are essentially constant over time, either rising or falling at the same rate or time invariant. The one exception is that the gap between men and women's $\mathrm{P}_{\mathrm{OE}}$ 's is rising, as women's $\mathrm{P}_{\mathrm{OE}}$ 's are falling over time more rapidly than men's $\mathrm{P}_{\mathrm{OE}}$ 's.

Knowing the differences in these six transition probabilities $\left(\mathrm{P}_{\mathrm{EU}}, \mathrm{P}_{\mathrm{EO}}, \mathrm{P}_{\mathrm{UE}}, \mathrm{P}_{\mathrm{UO}}, \mathrm{P}_{\mathrm{OU}}, \mathrm{P}_{\mathrm{OE}}\right)$ for different groups in the population is important for identifying the source of unemployment and designing appropriate policy. Our analysis indicates that policy makers who are concerned with lowering women's unemployment rates in the Czech Republic and other post-communist 
countries should focus on learning why women are not being hired as readily as men (married women from unemployment and single women from out-of-the labor force) and need not be concerned with other flows (for e.g., whether they are leaving jobs -- voluntarily or involuntarily -- at a more rapid rate). Policy analysts might consider if existing policies are slowing down the flows either from the supply side or demand side of the market. For example, it is conceivable that married women are taking advantage of unemployment benefits (if their household income is sufficiently high) or women's lower probability of getting a job may be due to the effects of generous maternity benefits, in the Czech Republic as well as in other post-communist countries, which can make women more costly to employers than men. ${ }^{19}$ Much of the job growth in this period is driven by the new, small-scale, private sector. There is evidence that women are less likely to be employed in this sector and it is possible that costly maternity benefits make a difference in hiring decisions. Given the evidence from other studies of the negative effect of extensive maternity protection (e.g., Anker and Hein, 1985), it might behoove the Czech Republic and other post-communist countries to revisit their labor laws and test if shifting the burden of the cost of such laws from the employer to the taxpayer would level the playing field for women in the labor market. There are of course alternatives, such as giving men similar benefits as women, as is the case in Sweden.

\footnotetext{
${ }^{19}$ In the Czech Republic, for example, Chapter 7, of the most recent Labor Code (No. 65/1995) provides the following "working conditions for women":

The requirement that employers "reassign her temporarily to other work which is suitable for her" if her work poses hazard to her pregnancy [Section 153];

"If a woman taking care of a child younger than 15 or a pregnant woman requests shorter working time or some other suitable adjustment to the prescribed weekly working time, the employer is obliged to grant her request." [Section 156];

Entitling women to 28 weeks of maternity leave in connection with child birth; 'the employer is obliged to grant a woman additional maternity leave until her child reaches three years of age if she asks for it' [Section 157];

"The employer is obliged to grant a mother who is breast-feeding her child a special [paid] break for this purpose." [Section 161].
} 


\section{References}

Anker, Richard and Catherine Heine (1985) "Why Third World Urban Employers Usually Prefer Men," International Labour Review Geneva, 124 (1): 73-90.

Bellmann, Lutz, Saul Estrin, Hartmut Lehmann and Jonathan Wadsworth (1995) "The East German Labor Market in Transition: Gross Flow Estimates from Panel Data," Journal of Comparative Economics, 20(2): 139-170.

Brainerd, Elizabeth (2000) "Women in Transition: Changes in Gender Wage Differentials in Eastern Europe and the Former Soviet Union," Industrial \& Labor Relations Review 54(1): 138-162.

Bilsen, Valentin and Jozef Konings (1998) "Job Creation, Job Destruction and Growth of Newly Established, Privatized and State-owned Enterprises in Transition Economies: Survey Evidence from Romania, Bulgaria and Hungary," Journal of Comparative Economics, 26: 429-445.

Chase, Robert S. (1998) "Markets for Communist Human Capital: Returns to Education and Experience in Post-Communist Czech Republic and Slovakia." Industrial and Labor Relations Review, 51 (3): 401-423.

DeBoer, Larry and Michael C. Seeborg (1989) "The Unemployment Rates of Men and Women: A Transition Probability Analysis,” Industrial \& Labor Relations Review 42(3): 404-414.

Faggio, Giulia and Josef Konings (2001) "Job Creation, Job Destruction, and Employment Growth in Transition Countries in the 90s," IZA Discussion Paper No. 242.

Foley, Mark C. (1997), "Labor Market Dynamics in Russia,” Yale University, Economic Growth Center Discussion Paper No. 780.

Gora, Marek and Hartmut Lehmann (1995) "How Divergent is Regional Labour Market Adjustment in Poland?" in S. Scarpetta and A. Woergoetter (eds.) The Regional Dimension of Unemployment in Transition Countries: A Challenge for Labour Market and Social Policies, OECD, Paris.

Ham, John, Jan Svejnar and Katherine Terrell (1999) "Women's Unemployment during the Transition: Evidence from Czech and Slovak Micro Data," Economics of Transition, 7 (1): 4778 .

Juradja, Stepan and Katherine Terrell (2001) "What Explains the Speed of Reallocation During Periods of Massive Adjustment?" William Davidson Institute Working Paper No. 432.

Marston, Stephen T. (1976) "Employment Instability and High Unemployment Rates," Brookings Papers on Economic Activity, 1: 169-203. 
Myatt, Anthony and David Murrell (1990) "The Female/Male Unemployment Rate Differential" The Canadian Journal of Economics, 23(2): 312-322.

Orazem, Peter and Milan Vodopivec (1995) "Winners and Losers in Transition: Returns to Education, Experience and Gender in Slovenia," The World Bank Economic Review, Vol. 9, No. 2, pp. 201-230.

Nesporova, Alena (1998) Women in the Labor Market of Central and Eastern Europe. Budapest: International Labor Office.

Paukert, Liba (1995) "Economic Transition and Women's Employment in Four Central European Countries, 1989 - 1994," Labor Market Papers No. 7, International Labor Office Geneva.

Royalty, Anne Beeson (1998) "Job-to-Job and Job-to-Nonemployment Turnover by Gender and Education Level," Journal of Labor Economics 16(2): 392-422. 
Figure 1: Unemployment Rates (\%) for the Czech Republic by Gender and Marital Status
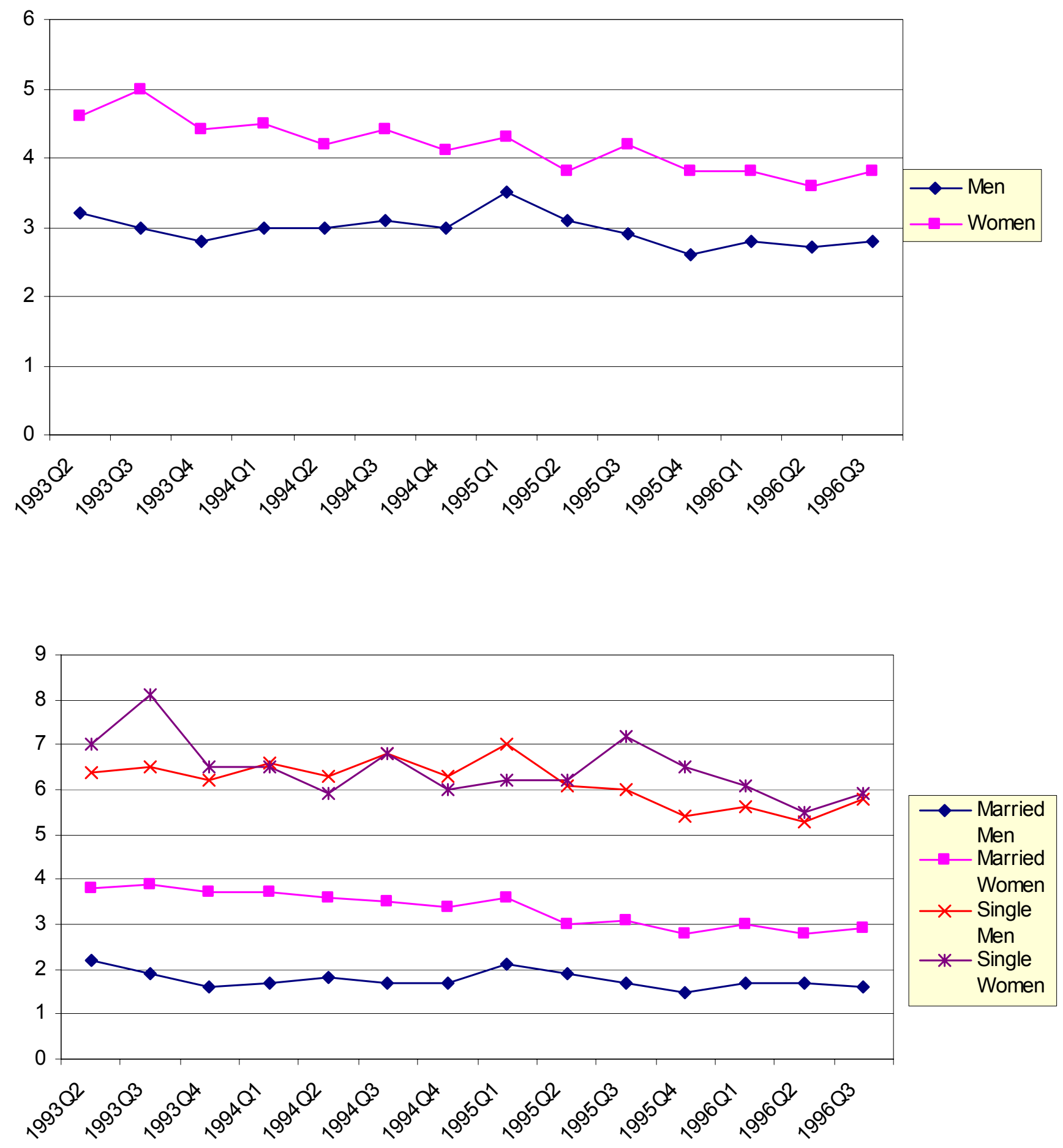
Table 1: Labor Force Participation Rates for Central and East European Countries by Gender

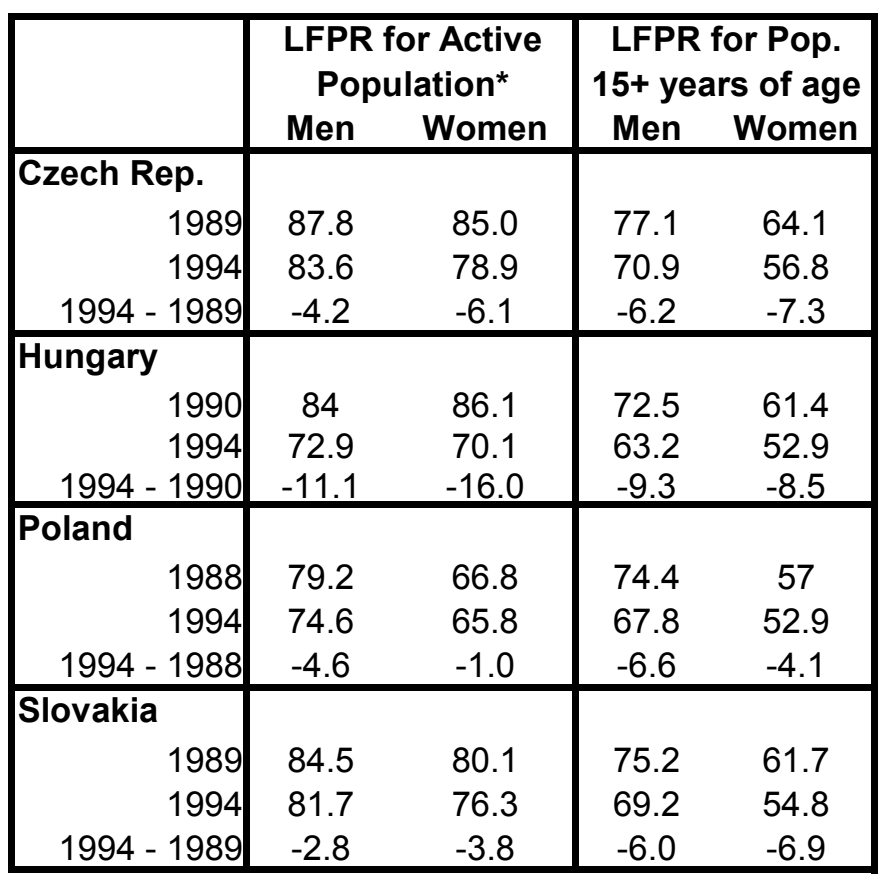

Source: Paukert (1995, p.46); data from National Statistical Yearbooks.

*The definition of "active population" varies across countries and it is different for men and for women within each country. For the Czech Republic, for example, it is $15-54$ for women and $15-59$ for men 
Table 2: Quarterly Labor Force Participation Rates by Gender and Age

\begin{tabular}{|c|c|c|c|c|c|c|}
\hline \multicolumn{7}{|c|}{ Men } \\
\hline & 94Q1 & 95Q1 & 96Q1 & 96Q4 & $\begin{array}{l}\text { 96Q1- } \\
\text { 94Q1 }\end{array}$ & $\begin{array}{l}\text { Avg. } \\
\text { (12Q) }\end{array}$ \\
\hline $15-19$ & 34.8 & 30.6 & 25.4 & 22.7 & -9.4 & 28.1 \\
\hline $20-24$ & 84.5 & 84.9 & 82.0 & 81.4 & -2.5 & 82.8 \\
\hline $25-29$ & 96.8 & 96.3 & 96.1 & 96.2 & -0.7 & 96.5 \\
\hline $30-34$ & 97.6 & 96.7 & 97.8 & 97.5 & 0.2 & 97.4 \\
\hline $35-39$ & 96.4 & 96.9 & 96.6 & 96.6 & 0.2 & 96.9 \\
\hline $40-44$ & 97.0 & 96.5 & 96.3 & 96.4 & -0.7 & 96.3 \\
\hline $45-49$ & 94.3 & 94.4 & 93.9 & 93.9 & -0.4 & 94.2 \\
\hline $50-54$ & 88.0 & 88.1 & 88.7 & 89.5 & 0.7 & 88.4 \\
\hline $55-59$ & 72.5 & 74.3 & 76.8 & 77.5 & 4.3 & 75.2 \\
\hline $60-64$ & 26.3 & 26.2 & 30.8 & 31.1 & 4.5 & 28.1 \\
\hline $65+$ & 9.9 & 8.7 & 9.1 & 8.8 & -0.8 & 9.2 \\
\hline Total $^{*}$ & 70.9 & 70.3 & 70.4 & 70.4 & -0.5 & 70.4 \\
\hline \multicolumn{7}{|c|}{ Women } \\
\hline & 94Q1 & 95Q1 & 96Q1 & 96Q4 & $\begin{array}{c}\text { 96Q1- } \\
\text { 94Q1 }\end{array}$ & $\begin{array}{l}\text { Avg. } \\
\text { (12Q) }\end{array}$ \\
\hline $15-19$ & 34.8 & 28.9 & 23.1 & 22.8 & -11.7 & 27.1 \\
\hline $20-24$ & 74.8 & 73.7 & 72.9 & 71.0 & -1.9 & 73.1 \\
\hline $25-29$ & 83.2 & 83.2 & 81.4 & 79.4 & -1.8 & 81.7 \\
\hline $30-34$ & 90.0 & 89.1 & 87.4 & 85.9 & -2.6 & 88.3 \\
\hline $35-39$ & 93.4 & 91.9 & 90.8 & 90.7 & -2.6 & 91.7 \\
\hline $40-44$ & 91.7 & 93.1 & 91.8 & 91.9 & 0.1 & 92.3 \\
\hline $45-49$ & 92.1 & 90.1 & 90.0 & 90.9 & -2.1 & 90.7 \\
\hline $50-54$ & 79.3 & 78.5 & 80.5 & 81.1 & 1.2 & 79.5 \\
\hline $55-59$ & 26.1 & 28.0 & 30.9 & 34.7 & 4.8 & 29.8 \\
\hline $60-64$ & 13.0 & 14.5 & 13.6 & 14.0 & 0.6 & 13.2 \\
\hline $65+$ & 3.4 & 3.1 & 3.4 & 3.3 & 0.0 & 3.4 \\
\hline Total* & 56.8 & 56.1 & 55.7 & 55.7 & -1.1 & 56.0 \\
\hline
\end{tabular}

Source: Labor Force Survey, Czech Statistical Office *LFPR for the population 15+ years of age. 
Table 3: Unemployment Rates by Gender in Selected Post-Communist Economies

\begin{tabular}{|c|c|c|c|c|c|c|c|c|c|c|}
\hline & 1991 & 1992 & 1993 & 1994 & 1995 & 1996 & 1997 & 1998 & 1999 & 2000 \\
\hline $\begin{array}{c}\text { Bulgaria } \\
\text { Men } \\
\text { Women }\end{array}$ & $\begin{array}{l}\text { n.a } \\
\text { n.a }\end{array}$ & $\begin{array}{l}\text { n.a } \\
\text { n.a }\end{array}$ & $\begin{array}{l}20.9 \\
22.0\end{array}$ & $\begin{array}{l}20.2 \\
20.3\end{array}$ & $\begin{array}{l}16.2 \\
16.8\end{array}$ & $\begin{array}{l}14.2 \\
14.1\end{array}$ & $\begin{array}{l}14.3 \\
14.4\end{array}$ & $\begin{array}{c}14.3 \\
\text { n.a }\end{array}$ & $\begin{array}{c}15.8 \\
\text { n.a }\end{array}$ & $\begin{array}{c}16.5 \\
\text { n.a }\end{array}$ \\
\hline \begin{tabular}{|c|} 
Czech \\
Republic \\
Men \\
Women \\
\end{tabular} & $\begin{array}{l}3.5^{*} \\
4.8^{*} \\
\end{array}$ & $\begin{array}{c}2.2 * \\
3^{*} \\
\end{array}$ & $\begin{array}{l}3.3 \\
5.3 \\
\end{array}$ & $\begin{array}{l}3.7 \\
5.1 \\
\end{array}$ & $\begin{array}{l}3.1 \\
4.5 \\
\end{array}$ & $\begin{array}{l}3.4 \\
4.9 \\
\end{array}$ & $\begin{array}{l}4.2 \\
6.9 \\
\end{array}$ & $\begin{array}{l}5.7 \\
9.3 \\
\end{array}$ & $\begin{array}{c}7.6 \\
10.7 \\
\end{array}$ & $\begin{array}{c}6.8 \\
10.2 \\
\end{array}$ \\
\hline $\begin{array}{c}\text { Germany } \\
\text { Men } \\
\text { Women } \\
\end{array}$ & $\begin{array}{l}5.4 \\
8.2 \\
\end{array}$ & $\begin{array}{c}6.2 \\
10.3 \\
\end{array}$ & $\begin{array}{c}7.8 \\
11.7 \\
\end{array}$ & $\begin{array}{c}8.9 \\
12.3 \\
\end{array}$ & $\begin{array}{c}8.7 \\
11.9 \\
\end{array}$ & $\begin{array}{l}8.2 \\
9.6 \\
\end{array}$ & $\begin{array}{c}9.2 \\
10.6 \\
\end{array}$ & $\begin{array}{c}9.2 \\
10.4 \\
\end{array}$ & $\begin{array}{l}8.4 \\
9.2 \\
\end{array}$ & $\begin{array}{l}7.6 \\
8.3 \\
\end{array}$ \\
\hline $\begin{array}{c}\text { Hungary } \\
\text { Men } \\
\text { Women } \\
\end{array}$ & $\begin{array}{l}9.2^{*} \\
7.6 \text { * }\end{array}$ & $\begin{array}{c}10.7 \\
8.7 \\
\end{array}$ & $\begin{array}{l}13.2 \\
10.4 \\
\end{array}$ & $\begin{array}{c}11.8 \\
9.4 \\
\end{array}$ & $\begin{array}{c}10.7 \\
8.7 \\
\end{array}$ & $\begin{array}{c}10.7 \\
8.8 \\
\end{array}$ & $\begin{array}{l}9.5 \\
7.8 \\
\end{array}$ & $\begin{array}{l}8.5 \\
7.0 \\
\end{array}$ & $\begin{array}{l}7.5 \\
6.3 \\
\end{array}$ & $\begin{array}{c}7 \\
5.6 \\
\end{array}$ \\
\hline $\begin{array}{c}\begin{array}{c}\text { Poland } \\
\text { Men } \\
\text { Women }\end{array} \\
\end{array}$ & $\begin{array}{l}10.6 \text { * } \\
13.5^{*}\end{array}$ & $\begin{array}{l}11.9 \text { * } \\
15.5^{*}\end{array}$ & $\begin{array}{l}12.6 \\
15.6 \\
\end{array}$ & $\begin{array}{l}13.1 \\
16.0 \\
\end{array}$ & $\begin{array}{l}12.1 \\
14.7 \\
\end{array}$ & $\begin{array}{c}11 \\
13.9 \\
\end{array}$ & $\begin{array}{c}9.6 \\
13.2 \\
\end{array}$ & $\begin{array}{c}9.1 \\
12.3 \\
\end{array}$ & $\begin{array}{l}12.4 \\
15.8 \\
\end{array}$ & $\begin{array}{l}14.4 \\
18.1 \\
\end{array}$ \\
\hline $\begin{array}{c}\text { Slovakia } \\
\text { Men } \\
\text { Women }\end{array}$ & $\begin{array}{l}6.4^{*} \\
6.9^{*}\end{array}$ & $\begin{array}{l}11.1^{*} \\
11.7^{*}\end{array}$ & $\begin{array}{l}12.5 \\
13.1\end{array}$ & $\begin{array}{l}13.3 \\
14.1 \\
\end{array}$ & $\begin{array}{l}12.6 \\
13.8 \\
\end{array}$ & $\begin{array}{l}10.2 \\
12.7\end{array}$ & $\begin{array}{l}10.9 \\
12.8\end{array}$ & $\begin{array}{l}11.9 \\
13.2\end{array}$ & $\begin{array}{l}16.0 \\
16.4\end{array}$ & $\begin{array}{l}18.6 \\
18.6\end{array}$ \\
\hline $\begin{array}{c}\text { Slovenia } \\
\text { Men } \\
\text { Women }\end{array}$ & $\begin{array}{l}8.5^{*} \\
7.9^{*}\end{array}$ & $\begin{array}{l}12.1 \text { * } \\
10.8^{*}\end{array}$ & $\begin{array}{l}9.9 \\
8.3\end{array}$ & $\begin{array}{l}9.5 \\
8.4\end{array}$ & $\begin{array}{l}7.7 \\
7.0\end{array}$ & $\begin{array}{l}7.5 \\
7.0\end{array}$ & $\begin{array}{l}7.0 \\
7.3\end{array}$ & $\begin{array}{l}7.6 \\
7.7\end{array}$ & $\begin{array}{l}7.2 \\
7.6\end{array}$ & $\begin{array}{l}\text { n.a } \\
\text { n.a }\end{array}$ \\
\hline \begin{tabular}{|c|} 
Russia \\
Men \\
Women \\
\end{tabular} & $\begin{array}{l}\text { n.a } \\
\text { n.a }\end{array}$ & $\begin{array}{l}5.2 \\
5.2 \\
\end{array}$ & $\begin{array}{l}5.9 \\
5.8 \\
\end{array}$ & $\begin{array}{l}8.3 \\
7.9 \\
\end{array}$ & $\begin{array}{l}9.7 \\
9.2 \\
\end{array}$ & $\begin{array}{c}10.0 \\
9.3 \\
\end{array}$ & $\begin{array}{l}12.2 \\
11.5 \\
\end{array}$ & $\begin{array}{l}13.6 \\
13.0 \\
\end{array}$ & $\begin{array}{l}13.6 \\
13.1 \\
\end{array}$ & $\begin{array}{l}\text { n.a } \\
\text { n.a }\end{array}$ \\
\hline $\begin{array}{c}\text { Ukraine } \\
\text { Men } \\
\text { Women }\end{array}$ & $\begin{array}{l}\text { n.a } \\
\text { n.a }\end{array}$ & $\begin{array}{l}\text { n.a } \\
\text { n.a }\end{array}$ & $\begin{array}{l}0.2^{*} \\
0.6^{*}\end{array}$ & $\begin{array}{l}0.2^{*} \\
0.6^{*}\end{array}$ & $\begin{array}{l}6.3 \\
4.9\end{array}$ & $\begin{array}{l}8.0 \\
7.3\end{array}$ & $\begin{array}{l}9.5 \\
8.4\end{array}$ & $\begin{array}{l}11.9 \\
10.8\end{array}$ & $\begin{array}{l}12.2 \\
11.5\end{array}$ & $\begin{array}{l}11.7 \\
11.7\end{array}$ \\
\hline
\end{tabular}

Source: National Labor Force Survey data unless indicated by * which is registered unemployment data, I.L.O. Yearbook of Labour Statistics, 2001.

Note: n.a. means not available 
Table 4: Average Quarterly Gross Transition Probabilities for 2Q93-4Q96 by Gender and Marital Status in the Czech Republic (in \%)

(Standard errors are in italics)

\begin{tabular}{|c|c|c|c|c|c|c|c|c|c|}
\hline & \multicolumn{2}{|c|}{ All } & \multicolumn{2}{|c|}{ Married } & \multicolumn{2}{|c|}{ Single } & \multicolumn{3}{|c|}{ Difference } \\
\hline & Men & Women & Men & Women & Men & Women & M-W & MM-MW & SM-SW \\
\hline \multirow{2}{*}{$\mathbf{P}_{\mathrm{EE}}$} & 98.28 & 97.79 & 98.68 & 98.04 & 97.22 & 97.08 & 0.49 & 0.64 & 0.14 \\
\hline & 0.004 & 0.005 & 0.004 & 0.006 & 0.01 & 0.011 & 0.007 & 0.007 & 0.015 \\
\hline \multirow[t]{2}{*}{$\mathbf{P}_{\mathrm{EU}}$} & 0.61 & 0.74 & 0.43 & 0.64 & 1.1 & 1.03 & -0.13 & -0.21 & 0.07 \\
\hline & 0.032 & 0.034 & 0.037 & 0.04 & 0.062 & 0.066 & 0.047 & 0.055 & 0.091 \\
\hline \multirow[t]{2}{*}{$P_{\mathrm{EO}}$} & 1.11 & 1.47 & 0.89 & 1.33 & 1.69 & 1.88 & -0.36 & -0.44 & -0.19 \\
\hline & 0.032 & 0.034 & 0.037 & 0.04 & 0.062 & 0.066 & 0.047 & 0.054 & 0.091 \\
\hline \multirow[t]{2}{*}{$\mathbf{P}_{\mathrm{UE}}$} & 26.72 & 23.18 & 27.34 & 21.33 & 26.11 & 25.68 & 3.54 & 6.01 & 0.43 \\
\hline & 0.157 & 0.144 & 0.239 & 0.191 & 0.21 & 0.219 & 0.213 & 0.306 & 0.303 \\
\hline \multirow{2}{*}{$P_{u U}$} & 66.54 & 69.36 & 66.08 & 70.37 & 67.07 & 67.95 & -2.82 & -4.29 & -0.88 \\
\hline & 0.106 & 0.09 & 0.164 & 0.117 & 0.14 & 0.144 & 0.14 & 0.201 & 0.201 \\
\hline \multirow[t]{2}{*}{$P_{\text {uo }}$} & 6.74 & 7.46 & 6.58 & 8.3 & 6.82 & 6.37 & -0.72 & -1.72 & 0.45 \\
\hline & 0.177 & 0.157 & 0.271 & 0.206 & 0.236 & 0.246 & 0.237 & 0.341 & 0.34 \\
\hline \multirow[t]{2}{*}{$\mathrm{P}_{\mathrm{OE}}$} & 2.48 & 1.72 & 1.41 & 1.72 & 3.8 & 1.71 & 0.76 & -0.31 & 2.09 \\
\hline & 0.047 & 0.037 & 0.063 & 0.056 & 0.07 & 0.051 & 0.06 & 0.084 & 0.086 \\
\hline \multirow[t]{2}{*}{$P_{\text {ou }}$} & 0.50 & 0.52 & 0.19 & 0.52 & 0.89 & 0.52 & -0.02 & -0.33 & 0.37 \\
\hline & 0.047 & 0.038 & 0.063 & 0.056 & 0.071 & 0.051 & 0.06 & 0.085 & 0.087 \\
\hline \multirow[t]{2}{*}{$P_{\text {oo }}$} & 97.02 & 97.76 & 98.41 & 97.77 & 95.32 & 97.77 & -0.74 & 0.64 & -2.45 \\
\hline & 0.008 & 0.006 & 0.008 & 0.008 & 0.015 & 0.008 & 0.004 & 0.012 & 0.017 \\
\hline
\end{tabular}

Note: MM - married men, MW - married women,

Source: Authors' calculations based on Labor Force Survey data. 
Table 5: Annual Gross Transition from Probabilities by Gender for Three Post-Communist Economies (in \%)

\begin{tabular}{|c|c|c|c|c|c|c|c|c|c|c|c|c|}
\hline & \multicolumn{3}{|c|}{$\begin{array}{c}\text { East Germany (a) } \\
1990-91\end{array}$} & \multicolumn{3}{|c|}{$\begin{array}{c}\text { Poland (b) } \\
1993-94 \\
\end{array}$} & \multicolumn{6}{|c|}{ Russia (c) } \\
\hline & Men & Women & $M-W$ & Men & Women & $M-W$ & Men & Women & M-W & Men & Women & $M-W$ \\
\hline $\mathbf{P}_{\mathrm{EU}}$ & 5.7 & 13.2 & -7.5 & 4.6 & 3.2 & 1.4 & 3.4 & 2.9 & 0.5 & 6.9 & 4.4 & 2.5 \\
\hline $\mathbf{P}_{\text {EO }}$ & 7.9 & 6.2 & 1.7 & 5.2 & 7.6 & -2.4 & 4.3 & 7.2 & -2.9 & 4.7 & 7.8 & -3.1 \\
\hline $\mathbf{P}_{\mathrm{UE}}$ & 39.9 & 31.5 & 8.4 & 41.8 & 29.6 & 12.2 & 53.5 & 50.8 & 2.7 & 41.0 & 37.8 & 3.2 \\
\hline$P_{\text {uo }}$ & 33.1 & 23.7 & 9.4 & 10.6 & 20.7 & -10.1 & 9.2 & 20.6 & -11.4 & 10.0 & 19.9 & -9.9 \\
\hline $\mathbf{P}_{\mathrm{OE}}$ & 13.5 & 17.2 & -3.7 & 8.0 & 7.0 & 1.0 & 8.0 & 8.9 & -0.9 & 6.4 & 8.0 & -1.6 \\
\hline $\mathbf{P}_{\text {OU }}$ & 1.6 & 5.4 & -3.8 & 4.0 & 4.4 & -0.4 & 1.7 & 1.3 & 0.4 & 4.4 & 3.0 & 1.4 \\
\hline
\end{tabular}

Source:
(a) Bellmann et al. (1995).
(b) Gora and Lehmann (1995).
(c) Foley (1997) 
Table 6: Multinominal Logit Model -EMPLOYMENT Transitions, by Gender

(Standard errors are in parentheses)

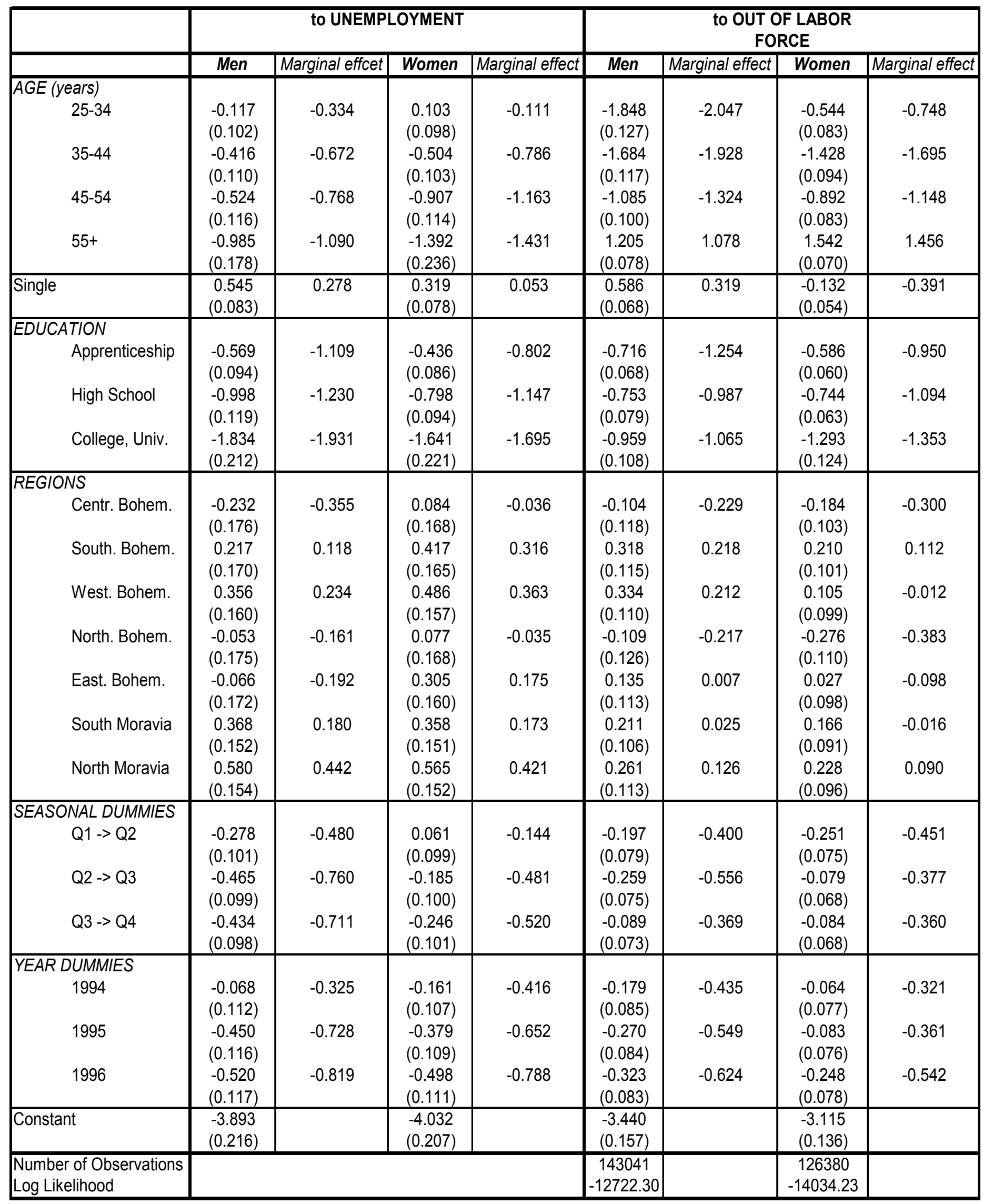

Source: Own computations using the Czech Labor Force Survey.

Note: The following are base groups: 15-24 years of age, elementary school level, Prague region, season Q4->Q1, year 1993 
Table 7: Multinomial Logit Model - UNEMPLOYMENT Transitions, by Gender

(Standard errors are in parentheses)

\begin{tabular}{|c|c|c|c|c|c|c|c|c|}
\hline & \multicolumn{4}{|c|}{ to EMPLOYMENT } & \multicolumn{4}{|c|}{$\begin{array}{c}\text { to OUT OF LABOR } \\
\text { FORCE }\end{array}$} \\
\hline & Men & Marginal effect & Women & Marginal effect & Men & Marginal effect & Women & Marginal effect \\
\hline AGE (years) & & & & & & & & \\
\hline $25-34$ & $\begin{array}{l}-0.249 \\
(0.134)\end{array}$ & -0.363 & $\begin{array}{l}-0.256 \\
(0.129)\end{array}$ & -0.453 & $\begin{array}{l}-0.408 \\
(0.202)\end{array}$ & -0.492 & $\begin{array}{l}-0.163 \\
(0.174)\end{array}$ & -0.375 \\
\hline $35-44$ & $\begin{array}{l}-0.449 \\
(0.141)\end{array}$ & -0.528 & $\begin{array}{l}0.069 \\
(0.132)\end{array}$ & -0.145 & $\begin{array}{l}-0.500 \\
(0.207)\end{array}$ & -0.570 & $\begin{array}{l}-0.266 \\
(0.185)\end{array}$ & -0.423 \\
\hline $45-54$ & $\begin{array}{l}-0.393 \\
(0.155)\end{array}$ & -0.450 & $\begin{array}{l}0.044 \\
(0.151)\end{array}$ & -0.096 & $\begin{array}{l}-0.314 \\
(0.218)\end{array}$ & -0.385 & $\begin{array}{l}0.266 \\
(0.189)\end{array}$ & 0.089 \\
\hline $55+$ & $\begin{array}{l}-2.237 \\
(0.208) \\
\end{array}$ & -1.905 & $\begin{array}{l}-1.920 \\
(0.214) \\
\end{array}$ & -1.164 & $\begin{array}{c}0.025 \\
(0.219) \\
\end{array}$ & -0.066 & $\begin{array}{c}0.106 \\
(0.203) \\
\end{array}$ & 0.043 \\
\hline Single & $\begin{array}{l}-0.236 \\
(0.112) \\
\end{array}$ & -0.644 & $\begin{array}{c}0.430 \\
(0.106) \\
\end{array}$ & 0.016 & $\begin{array}{c}0.136 \\
(0.158) \\
\end{array}$ & -0.341 & $\begin{array}{l}-0.148 \\
(0.134) \\
\end{array}$ & -0.465 \\
\hline EDUCATION & & & & & & & & \\
\hline Apprenticeship & $\begin{array}{c}0.579 \\
(0.110)\end{array}$ & 0.064 & $\begin{array}{c}0.493 \\
(0.105)\end{array}$ & 0.080 & $\begin{array}{c}0.164 \\
(0.151)\end{array}$ & -0.273 & $\begin{array}{l}-0.168 \\
(0.132)\end{array}$ & -0.470 \\
\hline High School & $\begin{array}{c}0.846 \\
(0.146)\end{array}$ & 0.572 & $\begin{array}{c}0.632 \\
(0.117)\end{array}$ & 0.326 & $\begin{array}{c}0.456 \\
(0.194)\end{array}$ & 0.255 & $\begin{array}{c}0.141 \\
(0.143)\end{array}$ & -0.082 \\
\hline College, Univ. & $\begin{array}{c}0.996 \\
(0.239) \\
\end{array}$ & 0.776 & $\begin{array}{c}0.517 \\
(0.246) \\
\end{array}$ & 0.409 & $\begin{array}{c}0.077 \\
(0.322) \\
\end{array}$ & 0.028 & $\begin{array}{l}-0.033 \\
(0.330) \\
\end{array}$ & -0.048 \\
\hline REGIONS & & & & & & & & \\
\hline Centr. Bohem. & $\begin{array}{l}0.268 \\
(0.200)\end{array}$ & 0.133 & $\begin{array}{l}0.766 \\
(0.185)\end{array}$ & 0.528 & $\begin{array}{l}-0.643 \\
(0.290)\end{array}$ & -0.608 & $\begin{array}{l}-0.024 \\
(0.246)\end{array}$ & -0.129 \\
\hline South. Bohem. & $\begin{array}{l}0.994 \\
(0.222)\end{array}$ & 0.753 & $\begin{array}{l}1.320 \\
(0.206)\end{array}$ & 1.037 & $\begin{array}{l}-0.066 \\
(0.317)\end{array}$ & -0.109 & $\begin{array}{c}0.295 \\
(0.281)\end{array}$ & 0.184 \\
\hline West. Bohem. & $\begin{array}{c}0.874 \\
(0.198)\end{array}$ & 0.622 & $\begin{array}{c}0.916 \\
(0.181)\end{array}$ & 0.661 & $\begin{array}{l}-0.084 \\
(0.276)\end{array}$ & -0.157 & $\begin{array}{c}0.151 \\
(0.243)\end{array}$ & 0.025 \\
\hline North. Bohem. & $\begin{array}{c}0.202 \\
(0.203)\end{array}$ & 0.036 & $\begin{array}{c}0.102 \\
(0.186)\end{array}$ & -0.062 & $\begin{array}{l}-0.520 \\
(0.274)\end{array}$ & -0.551 & $\begin{array}{l}-0.490 \\
(0.247)\end{array}$ & -0.555 \\
\hline East. Bohem. & $\begin{array}{c}0.738 \\
(0.205)\end{array}$ & 0.518 & $\begin{array}{c}0.788 \\
(0.192)\end{array}$ & 0.567 & $\begin{array}{c}0.086 \\
(0.267)\end{array}$ & -0.012 & $\begin{array}{c}0.418 \\
(0.240)\end{array}$ & 0.259 \\
\hline South Moravia & $\begin{array}{c}0.953 \\
(0.186)\end{array}$ & 0.626 & $\begin{array}{c}1.314 \\
(0.183)\end{array}$ & 0.964 & $\begin{array}{c}0.383 \\
(0.237)\end{array}$ & 0.163 & $\begin{array}{c}0.671 \\
(0.229)\end{array}$ & 0.429 \\
\hline North Moravia & $\begin{array}{r}0.889 \\
(0.190) \\
\end{array}$ & 0.552 & $\begin{array}{r}1.160 \\
(0.183) \\
\end{array}$ & 0.820 & $\begin{array}{c}0.150 \\
(0.247) \\
\end{array}$ & -0.049 & $\begin{array}{r}0.387 \\
(0.232) \\
\end{array}$ & 0.176 \\
\hline SEASONAL DUMMIES & & & & & & & & \\
\hline Q1 -> Q2 & $\begin{array}{c}0.428 \\
(0.141)\end{array}$ & 0.178 & $\begin{array}{c}0.548 \\
(0.131)\end{array}$ & 0.283 & $\begin{array}{c}0.242 \\
(0.189)\end{array}$ & 0.027 & $\begin{array}{c}0.335 \\
(0.162)\end{array}$ & 0.106 \\
\hline Q2 -> Q3 & $\begin{array}{c}0.382 \\
(0.136)\end{array}$ & 0.059 & $\begin{array}{c}0.189 \\
(0.130)\end{array}$ & -0.087 & $\begin{array}{c}0.152 \\
(0.185)\end{array}$ & -0.128 & $\begin{array}{l}-0.225 \\
(0.170)\end{array}$ & -0.431 \\
\hline Q3 -> Q4 & $\begin{array}{c}0.289 \\
(0.135) \\
\end{array}$ & 0.007 & $\begin{array}{c}0.360 \\
(0.126) \\
\end{array}$ & 0.052 & $\begin{array}{l}-0.069 \\
(0.189) \\
\end{array}$ & -0.285 & $\begin{array}{c}0.106 \\
(0.160) \\
\end{array}$ & -0.160 \\
\hline YEAR DUMMIES & & & & & & & & \\
\hline 1994 & $\begin{array}{c}0.217 \\
(0.146)\end{array}$ & -0.032 & $\begin{array}{l}-0.041 \\
(0.131)\end{array}$ & -0.265 & $\begin{array}{c}0.257 \\
(0.211)\end{array}$ & 0.001 & $\begin{array}{l}-0.011 \\
(0.178)\end{array}$ & -0.240 \\
\hline 1995 & $\begin{array}{l}-0.137 \\
(0.141)\end{array}$ & -0.353 & $\begin{array}{l}-0.165 \\
(0.132)\end{array}$ & -0.363 & $\begin{array}{c}0.070 \\
(0.204)\end{array}$ & -0.185 & $\begin{array}{c}0.038 \\
(0.176)\end{array}$ & -0.194 \\
\hline 1996 & $\begin{array}{l}-0.035 \\
(0.146)\end{array}$ & -0.258 & $\begin{array}{c}-0.198 \\
(0.137)\end{array}$ & -0.390 & $\begin{array}{c}0.043 \\
(0.211) \\
\end{array}$ & -0.194 & $\begin{array}{l}-0.151 \\
(0.184)\end{array}$ & -0.351 \\
\hline Constant & $\begin{array}{l}-0.935 \\
(0.260)\end{array}$ & & $\begin{array}{c}-1.390 \\
(0.252)\end{array}$ & & $\begin{array}{l}-1.707 \\
(0.353)\end{array}$ & & $\begin{array}{l}-1.435 \\
(0.323)\end{array}$ & \\
\hline $\begin{array}{l}\text { Number of Observations } \\
\text { Log Likelihood }\end{array}$ & & & & & $\begin{array}{c}4127 \\
-2486.51\end{array}$ & & $\begin{array}{c}5327 \\
-3036.31\end{array}$ & \\
\hline
\end{tabular}

Source: Own computations using the Czech Labor Force Survey

Note: The following are base groups: 15-24 years of age, elementary school level, Prague region, season Q4 -> Q1, year 1993 
Table 8: Multinomial Logit Model - OUT OF LABOR FORCE Transitions, by Gender

(Standard errors are in parentheses)

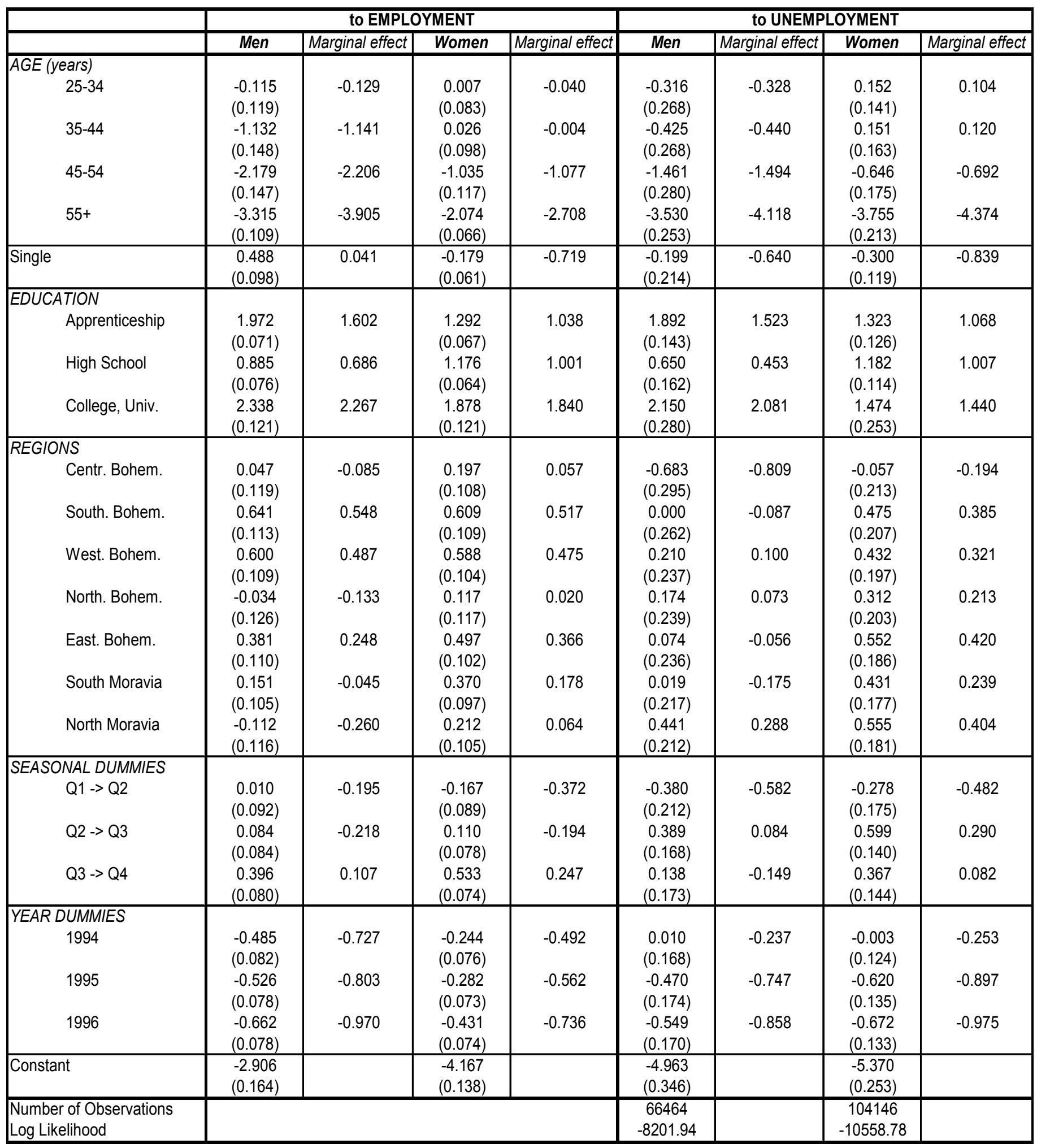

Source: Own computations using the Czech Labor Force Survey

Note: The following are base groups: 15-24 years of age, elementary school level, Prague region, season Q4 -> Q1, year 1993 
Appendix Table A1: Summary Statistics for the Czech Republic (pooled data)

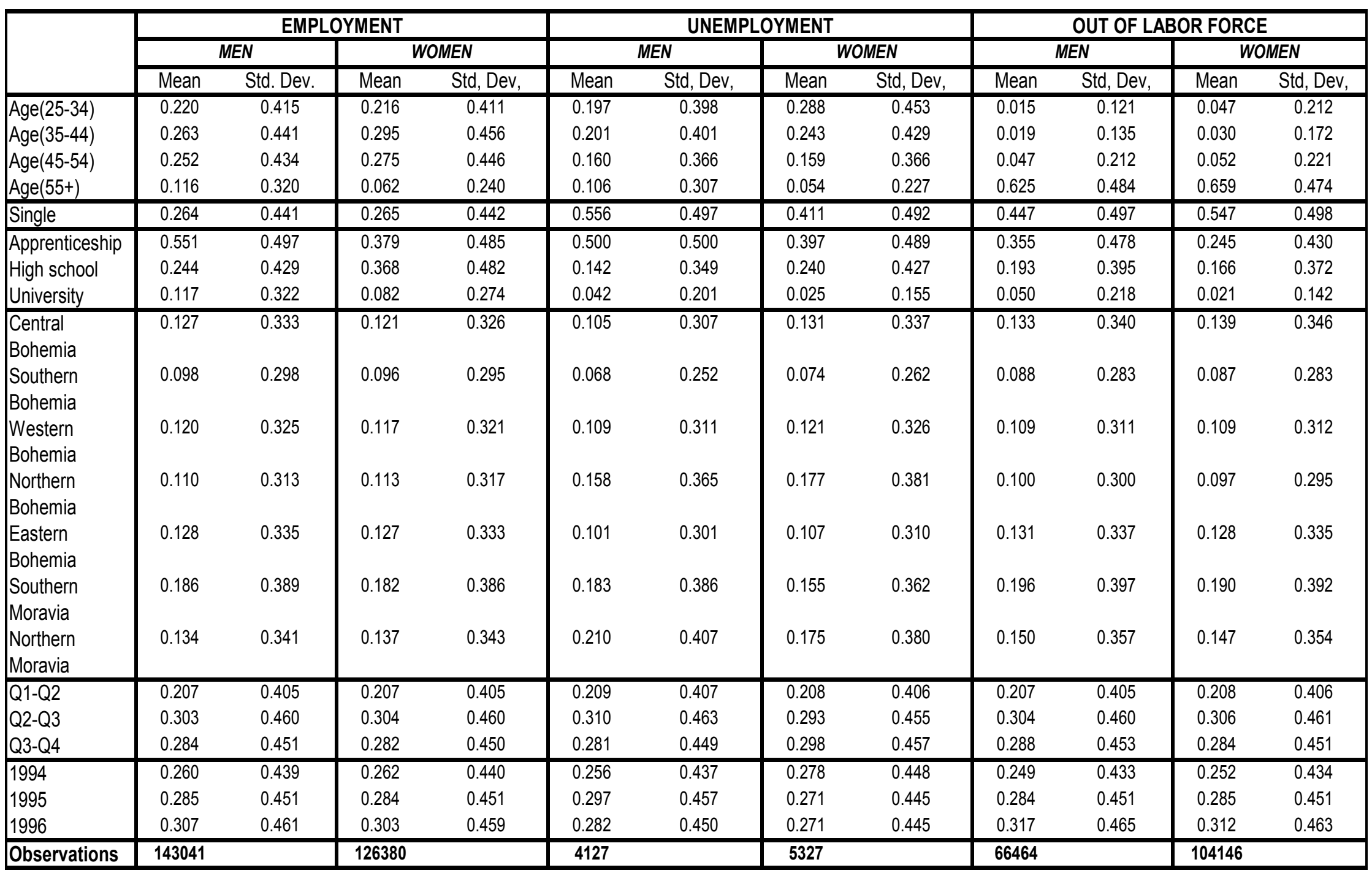

Source: Czech Labor Force Survey data 
Table A2: Differences in Transition Probabilities, by Gender (quarterly)

(standard error below the difference)

\begin{tabular}{|c|c|c|c|c|c|c|c|c|c|c|c|c|c|c|}
\hline & $932-933$ & 933-934 & $934-941$ & $941-942$ & $942-943$ & $943-944$ & $944-951$ & $951-952$ & $952-953$ & 953-954 & 954-961 & $961-962$ & $962-963$ & 963-964 \\
\hline \multirow[t]{2}{*}{ Diff EE } & 0.97 & 0.23 & 0.42 & 0.61 & 0.80 & 0.40 & 0.49 & 0.37 & 0.54 & 0.76 & 0.22 & 0.37 & 0.31 & 0.47 \\
\hline & 0.002 & 0.002 & 0.002 & 0.002 & 0.002 & 0.002 & 0.002 & 0.002 & 0.002 & 0.002 & 0.002 & 0.002 & 0.002 & 0.002 \\
\hline \multirow[t]{2}{*}{ Diff EU } & -0.39 & 0.04 & -0.02 & -0.19 & -0.16 & -0.05 & -0.03 & -0.23 & -0.14 & -0.21 & -0.12 & -0.14 & -0.04 & -0.22 \\
\hline & 0.013 & 0.013 & 0.013 & 0.013 & 0.013 & 0.013 & 0.013 & 0.012 & 0.012 & 0.012 & 0.012 & 0.012 & 0.012 & 0.012 \\
\hline \multirow[t]{2}{*}{ Diff EO } & -0.57 & -0.28 & -0.4 & -0.42 & -0.65 & -0.35 & -0.45 & -0.14 & -0.4 & -0.55 & -0.09 & -0.23 & -0.28 & -0.25 \\
\hline & 0.013 & 0.013 & 0.013 & 0.013 & 0.013 & 0.013 & 0.013 & 0.012 & 0.012 & 0.012 & 0.012 & 0.012 & 0.012 & 0.012 \\
\hline \multirow[t]{2}{*}{ Diff UE } & 4.28 & 5.38 & 3.58 & 4.19 & 6.46 & 0.29 & -0.44 & 0.94 & 6.11 & 1.6 & 2.04 & 3.02 & 7.18 & 4.95 \\
\hline & 0.056 & 0.055 & 0.06 & 0.056 & 0.058 & 0.056 & 0.059 & 0.053 & 0.056 & 0.054 & 0.06 & 0.057 & 0.06 & 0.057 \\
\hline \multirow[t]{2}{*}{ Diff UU } & -4.66 & -4.05 & -4.5 & -2.17 & -5.88 & 1.15 & -0.83 & 2.79 & -8.32 & 2.82 & -1.7 & -1.68 & -7.17 & -5.31 \\
\hline & 0.039 & 0.041 & 0.036 & 0.041 & 0.039 & 0.039 & 0.038 & 0.036 & 0.034 & 0.036 & 0.035 & 0.038 & 0.033 & 0.037 \\
\hline \multirow[t]{2}{*}{ Diff UO } & 0.38 & -1.32 & 0.92 & -2.03 & -0.58 & -1.44 & 1.26 & -3.72 & 2.21 & -4.41 & -0.34 & -1.34 & -0.01 & 0.36 \\
\hline & 0.064 & 0.064 & 0.066 & 0.064 & 0.065 & 0.064 & 0.065 & 0.059 & 0.061 & 0.061 & 0.064 & 0.062 & 0.065 & 0.064 \\
\hline \multirow[t]{2}{*}{ Diff OE } & 1.21 & 1.85 & 0.34 & 0.63 & 0.36 & 0.62 & 0.22 & 0.46 & 1.41 & 0.56 & 0.84 & 0.91 & 0.61 & 0.65 \\
\hline & 0.017 & 0.017 & 0.017 & 0.017 & 0.017 & 0.017 & 0.017 & 0.016 & 0.015 & 0.015 & 0.015 & 0.015 & 0.015 & 0.015 \\
\hline \multirow[t]{2}{*}{ Diff OU } & -0.25 & -0.08 & -0.12 & -0.09 & -0.08 & -0.08 & 0.02 & 0.04 & 0.10 & 0.08 & 0.19 & 0.04 & 0.01 & -0.02 \\
\hline & 0.017 & 0.017 & 0.017 & 0.017 & 0.017 & 0.017 & 0.017 & 0.016 & 0.015 & 0.015 & 0.015 & 0.015 & 0.015 & 0.015 \\
\hline \multirow[t]{2}{*}{ Diff 00} & $\begin{array}{l}-0.96 \\
\end{array}$ & -1.77 & $\begin{array}{l}-0.21 \\
\end{array}$ & -0.54 & -0.29 & -0.54 & -0.24 & -0.50 & -1.51 & -0.65 & -1.04 & $\begin{array}{l}-0.95 \\
\end{array}$ & -0.61 & -0.63 \\
\hline & 0.003 & 0.004 & 0.002 & 0.002 & 0.003 & 0.003 & 0.002 & 0.002 & 0.003 & 0.003 & 0.002 & 0.002 & 0.002 & 0.003 \\
\hline
\end{tabular}

Note : Each cell contains the differnce of gross flows (men - women) and it's standard error, respectively

Source: Own computations using the Czech Labor Force Survey 
William Davidson Institute Working Paper 506

Appendix Table A3: Differences in Transition Probabilities, by Marital Status (quarterly)

(standard errors below the difference)

Differences in transition probabilities of MARRIED men and women

\begin{tabular}{|c|c|c|c|c|c|c|c|c|c|c|c|c|c|c|}
\hline & $932-933$ & $933-934$ & $934-941$ & $941-942$ & $942-943$ & $943-944$ & $944-951$ & $951-952$ & $952-953$ & $953-954$ & $954-961$ & $961-962$ & $962-963$ & $963-964$ \\
\hline \multirow[t]{2}{*}{ Diff EE } & 0.83 & 0.39 & 0.60 & 0.58 & 0.85 & 0.64 & 0.69 & 0.57 & 0.58 & 1.18 & 0.40 & 0.61 & 0.41 & 0.58 \\
\hline & 0.002 & 0.002 & 0.002 & 0.002 & 0.002 & 0.002 & 0.002 & 0.002 & 0.002 & 0.002 & 0.002 & 0.002 & 0.002 & 0.002 \\
\hline \multirow[t]{2}{*}{ Diff EU } & -0.42 & -0.13 & -0.09 & -0.21 & -0.23 & -0.36 & -0.29 & -0.21 & -0.13 & -0.25 & -0.13 & -0.15 & -0.04 & -0.22 \\
\hline & 0.015 & 0.015 & 0.015 & 0.015 & 0.015 & 0.015 & 0.015 & 0.015 & 0.014 & 0.014 & 0.014 & 0.014 & 0.014 & 0.014 \\
\hline Diff EO & $\begin{array}{l}-\mathbf{0 . 4 1} \\
0.015\end{array}$ & $\begin{array}{l}-0.27 \\
0.015\end{array}$ & $\begin{array}{c}-0.52 \\
0.015\end{array}$ & $\begin{array}{l}-\mathbf{0 . 3 7} \\
0.015\end{array}$ & $\begin{array}{c}-\mathbf{0 . 6 2} \\
0.015\end{array}$ & $\begin{array}{l}-0.29 \\
0.015\end{array}$ & $\begin{array}{l}-\mathbf{0 . 3 9} \\
0.015\end{array}$ & $\begin{array}{r}-\mathbf{0 . 3 5} \\
0.015\end{array}$ & $\begin{array}{l}-\mathbf{0 . 4 5} \\
0.014\end{array}$ & $\begin{array}{l}-0.92 \\
0.014\end{array}$ & $\begin{array}{l}-\mathbf{0 . 2 6} \\
0.014\end{array}$ & $\begin{array}{c}-\mathbf{0} .48 \\
0.014\end{array}$ & $\begin{array}{l}-0.37 \\
0.014\end{array}$ & $\begin{array}{l}-0.35 \\
0.014\end{array}$ \\
\hline \multirow[t]{2}{*}{ Diff UE } & 2.47 & 9.80 & 10.65 & 5.39 & 9.50 & 3.95 & -0.42 & 4.12 & 11.27 & 6.85 & 1.36 & 3.20 & 5.87 & 10.12 \\
\hline & 0.075 & 0.079 & 0.085 & 0.08 & 0.082 & 0.083 & 0.085 & 0.074 & 0.079 & 0.08 & 0.091 & 0.082 & 0.085 & 0.084 \\
\hline \multirow[t]{2}{*}{ Diff UU } & -1.66 & -6.79 & -12.46 & -5.57 & -9.68 & -2.71 & -0.44 & 0.46 & -10.55 & -0.79 & 1.49 & 2.70 & -5.21 & -8.81 \\
\hline & 0.052 & 0.058 & 0.056 & 0.059 & 0.055 & 0.055 & 0.054 & 0.053 & 0.05 & 0.052 & 0.049 & 0.055 & 0.047 & 0.055 \\
\hline Diff UO & $\begin{array}{l}-0.81 \\
0.086\end{array}$ & $\begin{array}{c}-3.01 \\
0.09\end{array}$ & $\begin{array}{c}1.82 \\
0.095\end{array}$ & $\begin{array}{c}\mathbf{0 . 1 8} \\
0.092\end{array}$ & $\begin{array}{c}\mathbf{0 . 1 8} \\
0.091\end{array}$ & $\begin{array}{l}-1.24 \\
0.093\end{array}$ & $\begin{array}{c}\mathbf{0 . 8 6} \\
0.094\end{array}$ & $\begin{array}{l}-4.58 \\
0.084\end{array}$ & $\begin{array}{l}-0.73 \\
0.087\end{array}$ & $\begin{array}{l}-6.07 \\
0.089\end{array}$ & $\begin{array}{l}\mathbf{- 2 . 8 5} \\
0.096\end{array}$ & $\begin{array}{l}\mathbf{- 5 . 9 1} \\
0.091\end{array}$ & $\begin{array}{l}-0.66 \\
0.092\end{array}$ & $\begin{array}{l}-1.31 \\
0.095\end{array}$ \\
\hline \multirow[t]{2}{*}{ Diff OE } & -0.15 & -0.48 & -0.31 & 0.29 & -0.06 & -0.71 & -0.58 & 0.23 & -0.14 & -0.69 & -0.48 & -0.08 & -0.39 & -0.81 \\
\hline & 0.023 & 0.023 & 0.023 & 0.023 & 0.024 & 0.023 & 0.023 & 0.022 & 0.021 & 0.022 & 0.022 & 0.022 & 0.021 & 0.022 \\
\hline \multirow[t]{2}{*}{ Diff OU } & -0.26 & -0.63 & -0.76 & -0.43 & -0.6 & -0.43 & -0.33 & -0.03 & -0.23 & -0.19 & -0.09 & -0.18 & -0.19 & -0.26 \\
\hline & 0.024 & 0.024 & 0.024 & 0.024 & 0.023 & 0.023 & 0.024 & 0.022 & 0.021 & 0.022 & 0.022 & 0.022 & 0.021 & 0.022 \\
\hline Diff OO & $\begin{array}{c}0.41 \\
0.003\end{array}$ & $\begin{array}{c}1.12 \\
0.004\end{array}$ & $\begin{array}{c}1.09 \\
0.003\end{array}$ & $\begin{array}{c}0.14 \\
0.004\end{array}$ & $\begin{array}{c}\mathbf{0 . 6 5} \\
0.003\end{array}$ & $\begin{array}{c}1.14 \\
0.004\end{array}$ & $\begin{array}{c}0.91 \\
0.003\end{array}$ & $\begin{array}{l}-0.19 \\
0.003\end{array}$ & $\begin{array}{c}0.36 \\
0.003\end{array}$ & $\begin{array}{c}0.88 \\
0.003\end{array}$ & $\begin{array}{c}\mathbf{0 . 5 7} \\
0.003\end{array}$ & $\begin{array}{c}0.25 \\
0.003\end{array}$ & $\begin{array}{c}0.57 \\
0.003\end{array}$ & $\begin{array}{c}1.07 \\
0.003\end{array}$ \\
\hline
\end{tabular}

Differences in transition probabilities of SINGLE men and women

\begin{tabular}{|c|c|c|c|c|c|c|c|c|c|c|c|c|c|c|}
\hline & $932-933$ & $933-934$ & $934-941$ & $941-942$ & $942-943$ & $943-944$ & $944-951$ & $951-952$ & $952-953$ & $953-954$ & $954-961$ & $961-962$ & $962-963$ & $963-964$ \\
\hline \multirow[t]{2}{*}{ Diff EE } & 1.31 & -0.31 & -0.09 & 0.63 & 0.64 & -0.34 & -0.05 & -0.11 & 0.5 & -0.26 & -0.16 & -0.20 & 0.07 & 0.25 \\
\hline & 0.004 & 0.005 & 0.005 & 0.004 & 0.004 & 0.004 & 0.004 & 0.004 & 0.004 & 0.004 & 0.004 & 0.003 & 0.004 & 0.004 \\
\hline \multirow[t]{2}{*}{ Diff EU } & -0.24 & 0.54 & 0.2 & -0.08 & 0.06 & 0.81 & 0.67 & -0.27 & -0.19 & -0.14 & -0.15 & -0.13 & 0.01 & -0.23 \\
\hline & 0.027 & 0.026 & 0.025 & 0.025 & 0.025 & 0.025 & 0.025 & 0.024 & 0.023 & 0.023 & 0.023 & 0.023 & 0.023 & 0.023 \\
\hline Diff EO & $\begin{array}{l}-1.08 \\
0.027\end{array}$ & $\begin{array}{l}-0.23 \\
0.026\end{array}$ & $\begin{array}{c}-0.1 \\
0.025\end{array}$ & $\begin{array}{l}-0.55 \\
0.025\end{array}$ & $\begin{array}{c}-0.7 \\
0.025\end{array}$ & $\begin{array}{l}-0.47 \\
0.025\end{array}$ & $\begin{array}{l}-0.61 \\
0.025\end{array}$ & $\begin{array}{c}\mathbf{0 . 3 8} \\
0.024\end{array}$ & $\begin{array}{c}-0.3 \\
0.023\end{array}$ & $\begin{array}{c}\mathbf{0 . 4} \\
0.023\end{array}$ & $\begin{array}{c}\mathbf{0 . 3 1} \\
0.023\end{array}$ & $\begin{array}{c}0.33 \\
0.023\end{array}$ & $\begin{array}{l}-0.07 \\
0.023\end{array}$ & $\begin{array}{l}-0.02 \\
0.022\end{array}$ \\
\hline \multirow[t]{2}{*}{ Diff UE } & 7.04 & -0.74 & -3.75 & 2.10 & 0.20 & -5.37 & -1.07 & -2.01 & 1.01 & -4.35 & 2.55 & 2.80 & 7.98 & -0.37 \\
\hline & 0.086 & 0.078 & 0.088 & 0.08 & 0.084 & 0.077 & 0.084 & 0.078 & 0.079 & 0.073 & 0.081 & 0.08 & 0.085 & 0.078 \\
\hline \multirow[t]{2}{*}{ Diff UU } & -8.32 & -0.24 & 3.5 & 1.85 & -0.31 & 6.99 & -1.13 & 4.48 & -6.31 & 6.87 & -3.74 & -5.96 & -8.84 & -1.19 \\
\hline & 0.058 & 0.059 & 0.051 & 0.06 & 0.059 & 0.057 & 0.054 & 0.051 & 0.047 & 0.052 & 0.05 & 0.052 & 0.048 & 0.052 \\
\hline Diff UO & $\begin{array}{c}1.28 \\
0.096\end{array}$ & $\begin{array}{c}\mathbf{0 . 9 9} \\
0.092\end{array}$ & $\begin{array}{c}\mathbf{0 . 2 5} \\
0.096\end{array}$ & $\begin{array}{l}-3.96 \\
0.093\end{array}$ & $\begin{array}{c}\mathbf{0 . 1 1} \\
0.097\end{array}$ & $\begin{array}{c}-1.63 \\
0.09\end{array}$ & $\begin{array}{c}2.2 \\
0.094\end{array}$ & $\begin{array}{l}\mathbf{- 2 . 4 9} \\
0.086\end{array}$ & $\begin{array}{c}\mathbf{5 . 3} \\
0.086\end{array}$ & $\begin{array}{c}-2.52 \\
0.084\end{array}$ & $\begin{array}{c}1.18 \\
0.088\end{array}$ & $\begin{array}{c}3.17 \\
0.088\end{array}$ & $\begin{array}{c}\mathbf{0 . 8 6} \\
0.093\end{array}$ & $\begin{array}{c}1.56 \\
0.088\end{array}$ \\
\hline \multirow[t]{2}{*}{ Diff OE } & 3.37 & 5.29 & 1.17 & 0.91 & 1.02 & 2.31 & 1.04 & 0.66 & 3.18 & 2.13 & 2.22 & 1.89 & 1.72 & 2.28 \\
\hline & 0.024 & 0.025 & 0.025 & 0.025 & 0.024 & 0.024 & 0.024 & 0.023 & 0.021 & 0.021 & 0.022 & 0.021 & 0.021 & 0.021 \\
\hline \multirow[t]{2}{*}{ Diff OU } & 0.01 & 0.61 & 0.59 & 0.23 & 0.66 & 0.37 & 0.36 & 0.09 & 0.53 & 0.42 & 0.50 & 0.24 & 0.29 & 0.27 \\
\hline & 0.024 & 0.025 & 0.026 & 0.025 & 0.024 & 0.024 & 0.024 & 0.023 & 0.021 & 0.022 & 0.022 & 0.022 & 0.021 & 0.021 \\
\hline Diff O० & $\begin{array}{l}-3.36 \\
0.006\end{array}$ & $\begin{array}{l}\mathbf{- 5 . 9 2} \\
0.007\end{array}$ & $\begin{array}{l}-1.76 \\
0.004\end{array}$ & $\begin{array}{l}-1.14 \\
0.004\end{array}$ & $\begin{array}{l}-1.67 \\
0.005\end{array}$ & $\begin{array}{l}\mathbf{- 2 . 6 8} \\
0.005\end{array}$ & $\begin{array}{l}-1.40 \\
0.004\end{array}$ & $\begin{array}{l}-0.74 \\
0.003\end{array}$ & $\begin{array}{l}-3.70 \\
0.005\end{array}$ & $\begin{array}{l}\mathbf{- 2 . 5 6} \\
0.005\end{array}$ & $\begin{array}{l}\mathbf{- 2 . 7 0} \\
0.004\end{array}$ & $\begin{array}{l}-2.14 \\
0.003\end{array}$ & $\begin{array}{l}\mathbf{- 2 . 0 1} \\
0.004\end{array}$ & $\begin{array}{l}-2.55 \\
0.005\end{array}$ \\
\hline
\end{tabular}

Note: Each cell contains the difference of gross flows (men - women) and it's standard error

Source: Own computations using the Czech Labor Force Survey 


\section{DAVIDSON INSTITUTE WORKING PAPER SERIES - Most Recent Papers}

The entire Working Paper Series may be downloaded free of charge at: www.wdi.bus.umich.edu

CURRENT AS OF 10/2/02

\begin{tabular}{|c|c|c|}
\hline Publication & Authors & Date \\
\hline $\begin{array}{l}\text { No. 506: Explaining Gender Differences in Unemployment with Micro } \\
\text { Data on Flows in Post-Communist Economies }\end{array}$ & $\begin{array}{l}\text { Jana Stefanová Lauerová and } \\
\text { Katherine Terrell }\end{array}$ & Sep. 2002 \\
\hline No. 505: Bank Performance in Transition Economies & $\begin{array}{l}\text { Steven Fries, Damien Neven and } \\
\text { Paul Seabright }\end{array}$ & Sep. 2002 \\
\hline $\begin{array}{l}\text { No. 504: Does the Balassa-Samuelson Hypothesis Hold for Asian } \\
\text { Countries? An Empirical Analysis using Panel Data Cointegration Tests }\end{array}$ & Imed Drine and Christophe Rault & Sep. 2002 \\
\hline No. 503: Job Growth in Early Transition: Comparing Two Paths & $\begin{array}{l}\text { Štěpán Jurajda and Katherine } \\
\text { Terrell }\end{array}$ & Aug. 2002 \\
\hline $\begin{array}{l}\text { No. 502: Job Creation, Destruction and Transition in Poland, 1988- } \\
\text { 1998: Panel Evidence }\end{array}$ & $\begin{array}{l}\text { John E. Jackson and Bogdan } \\
\text { Mach }\end{array}$ & June 2002 \\
\hline $\begin{array}{l}\text { No. 501: Competition, Innovation and Growth in Transition: Exploring } \\
\text { the Interactions between Policies }\end{array}$ & $\begin{array}{l}\text { Philippe Aghion, Wendy Carlin } \\
\text { and Mark Schaffer }\end{array}$ & Mar. 2002 \\
\hline No. 500: Women in the LAC Labor Market: The Remarkable 1990's & $\begin{array}{l}\text { Suzanne Duryea, Alejandra Cox } \\
\text { Edwards and Manuelita Ureta }\end{array}$ & June 2001 \\
\hline $\begin{array}{l}\text { No. 499: Human Capital, Growth and Inequality in Transition } \\
\text { Economies }\end{array}$ & Michael Spagat & July 2002 \\
\hline No. 498: Understanding Czech Long-Term Unemployment & $\begin{array}{l}\text { Štěpán Jurajda and } \\
\text { Münich }\end{array}$ & Aug. 2002 \\
\hline $\begin{array}{l}\text { No. 497: Rent Seeking and Government Ownership of Firms: An } \\
\text { Application to China's Township-Village Enterprises }\end{array}$ & Jiahua Che & Sep. 2002 \\
\hline No. 496: Labor Market Flexibility in Central and East Europe & Jan Svejnar & Aug. 2002 \\
\hline $\begin{array}{l}\text { No. 495: When Information Dominates Comparison: A Panel Data } \\
\text { Analysis Using Russian Subjective Data }\end{array}$ & Claudia Senik & May 2002 \\
\hline No. 494: Corruption and Cross-Border Investment: Firm Level Evidence & $\begin{array}{l}\text { Beata K. Smarzynska } \\
\text { Jin Wei }\end{array}$ & Aug. 2002 \\
\hline $\begin{array}{l}\text { es of Long Memory Positive Weakly } \\
\text { es }\end{array}$ & Dmitri Koulikov & Aug. 2002 \\
\hline $\begin{array}{l}\text { No. 492: Effects of Ownership and Financial Status on Corporate } \\
\text { Environmental Performance }\end{array}$ & $\begin{array}{l}\text { Dietrich Earnhart and Lubomír } \\
\text { Lízal }\end{array}$ & Aug. 2002 \\
\hline $\begin{array}{l}\text { No. 491: Does Economic Uncertainty Have an Impact on Decisions to } \\
\text { Bear Children? Evidence from Eastern Germany }\end{array}$ & $\begin{array}{l}\text { Sumon Kumar Bhaumik and } \\
\text { Jeffrey B. Nugent }\end{array}$ & July 2002 \\
\hline $\begin{array}{l}\text { No. 490: The Reallocation of Workers and Jobs in Russian Industry: } \\
\text { New Evidence on Measures and Determinants }\end{array}$ & J. David Brown and John S. Earle & Aug. 2002 \\
\hline $\begin{array}{l}\text { No. 489: The Incidence and Cost of Job Loss in a Transition Economy: } \\
\text { Displaced Workers in Estonia, 1989-1999 }\end{array}$ & $\begin{array}{l}\text { Hartmut Lehmann } \\
\text { and Jonathan Wad }\end{array}$ & Aug. 2002 \\
\hline No. 488: Integration: An Empirical Assessment of Russia & $\begin{array}{l}\text { Daniel Berkowitz and David N. } \\
\text { DeJong }\end{array}$ & Feb. 2002 \\
\hline $\begin{array}{l}\text { No. 487: Dual Inflation under the Currency Board: The challenges of } \\
\text { Bulgarian EU accession }\end{array}$ & $\begin{array}{l}\text { Nikolay Nenovsky and Kalina } \\
\text { Dimitrova }\end{array}$ & July 2002 \\
\hline $\begin{array}{l}\text { No. 486: Worker Flows, Job Flows and Firm Wage Policies: } \\
\text { An Analysis of Slovenia }\end{array}$ & $\begin{array}{l}\text { John Haltiwanger and Milan } \\
\text { Vodopivec }\end{array}$ & July 2002 \\
\hline $\begin{array}{l}\text { No. 485: Do Schumpeterian Waves of Creative Destruction Lead to } \\
\text { Higher Productivity? Panel Data Evidence from Poland }\end{array}$ & Frederic Warzynski & July 2002 \\
\hline $\begin{array}{l}\text { No. 484: Labor Market Institutions and Restructuring: Evidence from } \\
\text { Regulated and Unregulated Labor Markets in Brazil }\end{array}$ & Jasper Hoek & July 2002 \\
\hline $\begin{array}{l}\text { No. 483: The Balassa-Samuelson effect in Central and Eastern Europe: } \\
\text { Myth or reality? }\end{array}$ & $\begin{array}{l}\text { Balázs Égert, Imed Drine, Kirsten } \\
\text { Lommatzsch and Christophe } \\
\text { Rault }\end{array}$ & July 2002 \\
\hline No. 482: Real Exchange Rates in Transition Economies & Boštjan Jazbec & July 2002 \\
\hline $\begin{array}{l}\text { No. 481: Labor Force Participation Dynamics in the Romanian Labor } \\
\text { Market }\end{array}$ & Alexandru Voicu & July 2002 \\
\hline
\end{tabular}

